\title{
METODE GARIS LATERAL DALAM SCILAB DAN APLIKASINYA DALAM FISIKA PERTANIAN SERTA MATEMATIKA KEUANGAN
}

Agah D. Garnadi ${ }^{a, 1, \dagger}$

S. Nurdiati ${ }^{1}$ 
${ }^{a}$ Research Cluster for Dynamics and Complex System,

FMIPA, Institut Pertanian Bogor,

${ }^{1}$ Dept. Matematika, Institut Pertanian Bogor

Jl. Meranti, Kampus IPB Darmaga, Bogor 16680

$\dagger$ Penulis/Editor Penanggungjawab

DOI :

DRAFT Versi 0.9 
METODE GARIS LATERAL DALAM SCILAB

DAN APLIKASINYA

DALAM FISIKA PERTANIAN SERTA MATEMATIKA KEUANGAN 
Dedikasi 
Blank 


\section{PRAKATA}

Buku cilik (buklik)/buklet ini, tersusun atas 4 bab utama, serta 2 bab tambahan. Bab pertama membahas mengenai landasan matematis dari metode garis lateral, kemudian diikuti 2 bab implementasi secara rinci dalam Fisika Pertanian dan Matematika Keuangan. Sementara 2 bab tambahan berupa bab mengenai rutin utama masalah syarat batas PDB dalam Scilab dan ringkasan perintah Scilab yang penting untuk memahami metode garis lateral di Bab 2 dan 3.

Berbagai studi kasus diberikan sebagai latihan. Studi kasus yang diberikan, berasal dari beberapa bidang yang berkaitan dengan aplikasi fisika pertanian dan Matematika Keuangan yang menjadi misi utama institusi. Bahkan beberapa studi kasus dirancang agar dapat digunakan untuk membantu penelitian mahasiswa $\mathrm{S} 1 / \mathrm{S} 2 / \mathrm{S} 3$, bahkan untuk penelitian yang sifatnya garda depan (research frontier).

Buklik ini, tidak disiapkan menjadi buku daras (text book), tetapi dapat digunakan sebagai pelengkap bahan praktikum Komputasi Matematika, maupun untuk bahan belajar.

Penulisan buklet/buklik ini merupakan output skim Penelitian Strategis Unggulan, hibah DIPA-IPB, 0558/023-04.2.01/12/2012, yang didanai oleh Kementrian Pendidikan dan Kebudayaan, Republik Indonesia, dengan kontrak no : 44/I3.24.4/SPK-PUS/IPB/2012.

BOGOR, 17 Agustus 2019 
Blank 


\section{DAFTAR ISI}

- Metode Garis Lateral

- Metode Garis Lateral untuk Pindah Panas Dalam Proses Pasca Panen

- Metode Garis Lateral untuk Opsi Eropa

- Metode Penyelesaian Masalah Syarat Batas dalam Scilab

- Scilab Singkat 
Blank 


\title{
MASALAH SYARAT BATAS BEBAS PERSAMAAN DIFERENSIAL PARSIAL PARABOLIK SATU-DIMENSI
}

\author{
AGAH D. GARNADI
}

\author{
Departemen Matematika, \\ Fakultas Matematika dan Ilmu Pengetahuan Alam, \\ Institut Pertanian Bogor \\ Jl. Raya Pajajaran, Kampus IPB Baranang Siang, Bogor, Indonesia
}

\begin{abstract}
Sering ditemui dalam proses difusi diperlukan penentuan satu permukaan bebas dari data di batas yang berlebih. Satu teknik penyelesaian konstruktif yang umum digunakan ialah metode garis. Tulisan ini memberikan langkah yang diambil untuk mendekati berbagai masalah syarat batas bebas yang eksplisit maupun implisit untuk persamaan difusi satu-dimensi dengan mempergunakan satu barisan masalah syarat batas dari satu persamaan diferensial biasa. Diperlihatkan bahwa persamaan ini memiliki solusi yang dapat diperoleh dengan mempergunakan teknik invariant imbedding. Juga diperlihatkan untuk satu model bahwa solusi hampiran akan konvergen ke solusi klasik yang (hampir) tunggal saat parameter diskretisasi menuju nol.
\end{abstract}

\section{Pendahuluan.}

Di antara sejumlah masalah syarat batas bebas untuk persamaan diferensial parsial, masalah parabolik satu dimensi boleh dikata telah dibahas sangat rinci. Satu masalah jenis tersebut yang cukup dimengerti dengan baik ialah masalah pelelehan batang es yang bersentuhan dengan bahan cair. Jika dianggap bahwa es selalu dalam keadaan suhunya terjaga pada suhu tetap $0^{\circ} \mathrm{C}$, dan perpindahan panas dianggap hanya melalui konduksi, maka distribusi suhu di batang es dapat diterangkan dengan persamaan panas berikut:

$$
u_{x x}-c u_{t}=0
$$

DIBIAYAI OLEH PROYEK PENINGKATAN IPB, KONTRAK NO XX/KXX.XX.X/SPHP/2004 
dengan syarat batas dan syarat awal:

$$
\begin{aligned}
u(0, t) & =\alpha(t), \\
u(s(t), t) & =0, \\
u_{x}(s(t), t) & =-\lambda \frac{d s}{d t}, \\
s(0) & =0 .
\end{aligned}
$$

Dengan notasi sebagai berikut, $u$ menyatakan suhu dalam fluida di antara dinding $x=0$ yang bersuhu $\alpha(t)$ dan batas $s(t)$ yang tidak diketahui dan bergerak sebagai batas antara fluida dan es. Syarat untuk flux $u_{x}(s(t), t)$ di atas, diperoleh dari neraca energi dan memiliki arti bahwa panas mengalir ke es digunakan untuk melelehkannya alih-alih untuk menaikkan suhu. Syarat $s(0)=0$ berarti tidak ada fluida pada awalnya. Konstanta $c$ dan $\lambda$ ditentukan dari konduktivitas, kapasitas panas dan panas laten dari air.

Masalah tersebut di atas dan perluasannya ke sistem dua fasa (dengan anggapan bahwa benda padatnya juga memiliki perubahan suhu) sudah dipelajari di akhir abad ke-19 oleh J. Stefan, sehingga kini dikenal sebagai masalah Stefan. Seiring dengan berjalannya waktu, muncul berbagai masalah teknik akibat perkembangan teknologi yang dapat dirumuskan sebagai masalah berjenis Stefan, akibatnya karya ilmiah yang membahas solusi masalah syarat batas bebas secara analitik mau pun numerik meningkat cukup berarti. Pembahasan mengenai perumusan masalah syarat batas bebas satu dimensi berkait dengan perubahan fasa, filtrasi, aliran viskoplastis dan proses tumbukan serta bahasan matematika yang rinci dari masalah yang muncul dari sejumlah model tertentu dapat ditemukan di monograf [32], yang mencatat perkembangan hingga dasa warsa 60'an, dan prosiding [26], serta seri yang mencantumkan judul Free and Moving Boundary Problem semisal [6], serta munculnya Jurnal Interface and Moving Boundary Problems yang berumur lebih dari sepuluh tahun, menandakan pentingnya model yang menyangkut batas bebas. Sementara itu,yang menurut hemat penulis, perlu diperhatikan mengingat bidang aplikasinya cukup dekat dengan masalah di Indonesia, berbagai masalah batas bebas bermunculan dari masalah matematika keuangan [39] [22],[23], dari teknologi pangan misalnya mengenai penggorengan dan pengeringan [9] dan pengeringan beku [10],[11], [24], [27],[2], [3]; teknologi penerbangan [12],[25]; serta pengeboran dengan laser dalam industri manufaktur [1], pembedahan dengan sinar laser [13], [28], pembedahan kulit sel telur dengan sinar laser [14].

Satu teknik yang dapat digunakan untuk menyelesaikan masalah syarat batas persamaan difusi satu dimensi dikenal dengan metode garis lateral. Pada prinsipnya, metode ini ialah mengganti persamaan diferensial parsial dengan satu barisan masalah syarat batas persamaan diferensial biasa. Secara historis, Rothe [30] mempergunakan strategi 
tersebut untuk masalah syarat batas parabolik dua dimensi di daerah yang tetap, sehingga metode garis lateral sering pula dikenal sebagai Metode Rothe. Strategi ini tidak hanya digunakan sebagai metode numerik $^{1}$, [5], juga digunakan untuk pembahasan analitik [16]. Bahkan, meski tidak dikutip oleh [32], metode ini sering digunakan untuk menyelesaikan masalah syarat batas bebas dan masalah interface (misalnya, [4], [17], [34], [35], [37], [38] serta rujukan yang dikutipnya). Semua karya tersebut cukup berbeda substansinya karena ragam masalah yang diselesaikannya, tetapi semua memiliki benang merah yang sama dan mempergunakan teknik matematika yang sama. ${ }^{2}$ Tulisan ini bertujuan memperlihatkan tahapan penting penggunaan Metode Rothe untuk menyelesaikan masalah syarat batas bebas. Dapat diidentifikasi bahwa dalam proses penyelesaian terdapat 5 tahapan penting,

(1) Perumusan dengan mempergunakan aproksimasi garis

(2) Penyelesaian rangkaian persamaan garis

(3) Penurunan batas a-priori dari penyelesaian persamaan garis

(4) Pendefinisian penyelesaian dari masalah syarat batas bebas yang diberikan

(5) Kekonvergenan penyelesaian metode garis.

Tahap 1 dan 2 bersifat algoritmik dan akan dirumuskan untuk masalah yang cukup umum. Hal penting ialah, tahap batas a-priori dan kekonvergenan solusi sangat tergantung pada data yang diberikan, karenanya hanya akan dibatasi pada satu masalah model. Cukup penting untuk dicatat, karya [19] cukup berbeda dibanding dengan karya lainnya dalam 2 hal. Tahap 2 digunakan teknik invariant imbedding, yang mengubah masalah syarat batas persamaan garis menjadi masalah syarat awal, dan langkah ke 5 yang mempergunakan konsep solusi lemah alihalih solusi klasik. Meski demikian, benang merah metodenya tetap tampak jelas serupa.

\footnotetext{
${ }^{1}$ Kelompok penelitian di Konrad Zusse Institut Berlin cukup extensif mempergunakan Metode Rothe, lihat kumpulan Technical Reports yang disediakan di homepagenya: http: www.zib.de.

${ }^{2}$ Penggunaan Metode Rothe tidak dibatasi untuk masalah parabolik, tetapi juga untuk persamaan eliptik, [21] memanfaatkannya untuk menyelesaikan Dam Problem yang merupakan masalah batas bebas persamaan Eliptik.
} 


\section{APROKSIMASI GARIS LATERAL DAN invariant imbedding.}

Tinjau permasalahan berikut

$$
\begin{aligned}
L u:=\left(\frac{\partial}{\partial x}\left(k(x, t) \frac{\partial}{\partial x}\right)+\right. & a(x, t) \frac{\partial}{\partial x}+b(x, t) \\
& -c(x, t) \frac{\partial}{\partial t} u=f(x, t), \\
& t>0, \quad 0<x<s(t), \\
\alpha_{1}(t) u(0, t)+\alpha_{2}(t) u_{x}(0, t)= & \alpha(t), \\
& \alpha_{1}(t)^{2}+\alpha_{2}(t)^{2} \neq 0, t>0, \\
u(x, 0)= & u_{0}(x), \quad 0<x<s(t),
\end{aligned}
$$

dengan kendala,

$$
H\left(u(s, t), u_{x}(s, t), u_{t}(s, t), s(t), s^{\prime}(t), t\right)=0, \quad t>0,
$$

dengan $H=\left(H_{1}, H_{2}\right)$ fungsi bernilai di $\mathrm{R}^{2}$ yang diberikan. Dalam pembahasan selanjutnya, semua data berupa fungsi dianggap memenuhi syarat cukup licin (smooth) yang diperlukan untuk operasi di daerah $\Omega_{\infty}=\{(x, t) ; 0 \leq x<\infty, 0 \leq t \leq T\}$, dengan $T$ sebarang tetapi merupakan batas atas yang tetap.

Perumusan di atas termasuk beragam masalah syarat batas bebas, antara lain:

(i.) Masalah Stefan

$$
H=\left(\begin{array}{l}
u \\
u_{x}+\lambda s^{\prime}
\end{array}\right)
$$

atau secara umum

$$
H=\left(\begin{array}{l}
u+\mu_{1}(s, t) \\
u_{x}+\lambda s^{\prime}+\mu_{2}(s, t)
\end{array}\right), \quad \lambda>0 .
$$

(ii.) Masalah teori optimal stopping [35] dan aliran plastis Bingham $[32]$

$$
H=\left(\begin{array}{l}
u \\
u_{x}
\end{array}\right) .
$$

(iii.) Masalah filtrasi satu fasa[34],[38]:

$$
H=\left(\begin{array}{l}
u-\mu_{1}(s, t) \\
u_{x}-\mu_{2}(s, t)
\end{array}\right) .
$$

(iv.) Model Gibbs-Thompson untuk pertumbuhan gelembung tunggal dalam larutan kimia [7]:

$$
H=\left(\begin{array}{l}
u+\mu_{1} e^{\mu_{2} / s} \\
u_{x}-\left(\mu_{3}-u\right) s^{\prime}
\end{array}\right)
$$


(v.) Radiasi dan ablasi di permukaan bebas

$$
H=\left(\begin{array}{c}
u-\mu_{1}\left(u^{4}-\mu_{1}^{4}\right) \\
s^{\prime}-\mu_{3} e^{\mu_{4} /\left(\mu_{5}-u\right)}
\end{array}\right) .
$$

Dengan semua $\mu_{i}$ bergantung pada $s$ dan $t$. Lebih jauh, hubungan fungsional di syarat batas bebas dapat diakomodir. (Lihat, misalnya, perumusan tumbukan viskoplastis [32], masalah perpindahan panas untuk pelapisan unggun mengalir [20], lihat juga proposal software di [36]).

Semua masalah di atas memiliki kesamaan yaitu berupa persamaan difusi, apakah berbentuk kartesian, radial, mau pun bola, dengan atau tanpa suku konveksi, dan dengan suku beban yang tergantung pada masalahnya, harus diselesaikan dengan syarat memenuhi hubungan affin (2.3) dan kedua hubungan (2.5). Jika $s(t)$ diberikan, masalah menjadi over-determined sehingga mungkin tak ada solusi. Akan tetapi, jika $s(t)$ tidak diketahui secara a-priori dan harus ditentukan sehingga data di batas yang diberikan menjadi konsisten. Jika salah satu persamaan di (2.5) dapat diselesaikan untuk $s(t)$ atau $s^{\prime}(t)$, maka masalah dikenal sebagai masalah syarat batas bebas eksplisit; lainnya disebut implisit. Masalah Stefan merupakan masalah eksplisit, sedangkan masalah optimal stopping merupakan perumusan implisit.

2.1. Metode garis lateral (Metode Rothe). Penggunaan metode garis lateral atau Metode Rothe dengan mudah diaplikasikan ke masalah di atas tanpa melakukan tambahan apa pun atas struktur persamaannya. Untuk itu, kita definisikan partisi $\left\{0=t_{0}<t_{1}<\cdots<t_{N}=T\right\}$ dari selang $[0, T]$, yang untuk kemudahan kita anggap terdiri dari subselang yang seragam: $\Delta t=t_{i}-t_{i-1}, i=1,2, \cdots, N$. Hal yang paling sederhana dan umum digunakannya metode Rothe untuk menghampiri (2.2) dengan melakukan substitusi berikut ini:

$$
\left.u_{t}\left(x, t_{n}\right) \approx \frac{u\left(x, t_{n}\right)-u\left(x, t_{n-1}\right)}{\Delta t}, \quad s^{\prime}\left(t_{n}\right) \approx \frac{s\left(t_{n}\right)-s\left(t_{n-1}\right.}{\Delta t}\right),
$$

yang akhirnya mereduksi persamaan diferensial parsial (2.2) menjadi satu barisan masalah syarat batas bebas untuk persamaan diferensial biasa berikut ini:

$$
\begin{aligned}
\left(k\left(x, t_{n}\right) u_{n}^{\prime}\right)^{\prime}+a\left(x, t_{n}\right) u_{n}^{\prime}+b\left(x, t_{n}\right)-c\left(x, t_{n}\right) \frac{u_{n}-u_{n-1}}{\Delta t} & \\
=f\left(x, t_{n}\right), & \\
n=1, \cdots, N, & \\
\alpha_{1}\left(t_{n}\right) u_{n}(0)+\alpha_{2}\left(t_{n}\right) u_{n}^{\prime}(0) & =\alpha\left(t_{n}\right) . \\
H\left(u_{n}\left(s_{n}\right), u_{n}^{\prime}\left(s_{n}\right), \frac{u_{n}\left(s_{n}\right)-u_{n-1}\left(s_{n}\right)}{\Delta t}, s_{n}, \frac{s_{n}-s_{n-1}}{\Delta t}, t_{n}\right) & =0,
\end{aligned}
$$


dengan $u_{n}=u\left(x, t_{n}\right), u_{n}^{\prime}=d / d x\left(u_{n}\right)$ dan $s_{n}=s\left(t_{n}\right)$. Untuk setiap tingkat waktu $n$, persamaan ini harus diselesaikan untuk fungsi $u_{n}$ dan batas bebas $s_{n}$ (bahkan bila diperlukan, $u_{n-1}$ dapat diperluas secara diferensial sebagai fungsi linear di $\left.\left[s_{n-1}, \infty\right)\right)$.

Untuk hampiran di atas, kita gunakan formula beda mundur untuk variabel waktu, yaitu metode diskretisasi implisit orde satu. Dapat juga digunakan misalnya metode implisit dengan orde lebih tinggi, seperti Crank-Nicholson, tetapi harus diperhatikan apakah tingkat akurasi untuk penentuan $s_{n}$ juga lebih baik. Begitu pula, formula beda maju dalam waktu dapat digunakan, tetapi untuk kasus batas bebas, kita berhadapan dengan masalah bahwa secara eksplisit kita harus mengetahui di mana posisi batas bebasnya. Karena itu lebih cenderung dipilih metode implisit, karena algoritma penyelesaian tidak tergantung secara langsung pada posisi $s_{n}$.

2.2. Invariant Imbedding. Perhatikan bahwa persamaan diferensial biasa di atas berbentuk linear dalam $u_{n}$. Kelinearan ini, dapat dimanfaatkan dengan cara lain untuk mengatasi ketakstabilan, setidaknya untuk masalah Stefan [33]. Teknik yang akan disajikan dikenal sebagai metode invariant imbedding dan secara rinci diuraikan di [17]. Kita akan berikan ringkasannya berikut ini. Masalah (2.12) dapat dituliskan sebagai sistem persamaan diferensial orde-1

$$
\begin{aligned}
u_{n}^{\prime}= & v_{n} / k\left(x, t_{n}\right), \\
v_{n}^{\prime}= & u_{n} \frac{c\left(x, t_{n}\right)}{\Delta t}-\frac{a\left(x, t_{n}\right)}{k\left(x, t_{n}\right)} v_{n} \\
& -b\left(x, t_{n}\right) u_{n}+f\left(x, t_{n}\right)-\frac{c\left(x, t_{n}\right)}{\Delta t} u_{n-1},
\end{aligned}
$$

dengan syarat batas yang diberikan. Agar tepatnya, kita anggap $\alpha_{2}(t) \neq$ 0 di $[0, T]$, dan untuk memudahkan, kita pilih $\alpha_{2}=1$. (Untuk kasus $\alpha_{1} \neq 0$, peran dari $u_{n}$ dan $v_{n}$ kita pertukarkan. Untuk rincinya lihat di [17] atau [18]). Sehingga syarat batas untuk sistem di atas, berbentuk:

$$
\begin{aligned}
v_{n} & =\left[\alpha\left(t_{n}\right)-\alpha_{1}\left(t_{n}\right) u_{n}(0)\right] \cdot k\left(0, t_{n}\right), \\
0 & =H\left(u_{n}\left(s_{n}\right), u_{n}^{\prime}\left(s_{n}\right), \frac{u_{n}\left(s_{n}\right)-u_{n-1}\left(s_{n}\right)}{\Delta t}, s_{n}, \frac{s_{n}-s_{n-1}}{\Delta t}, t_{n}\right) .
\end{aligned}
$$

Penyelesaian (2.13) dan (2.14), jika ada, termuat dalam keluarga fungsi $\left\{u_{n}(x, r), v_{n}(x, r)\right\}$ dari solusi (2.13) dengan syarat:

$$
\begin{aligned}
& v_{n}=\left[\alpha\left(t_{n}\right)-\alpha_{1}\left(t_{n}\right) u_{n}(0)\right] \cdot k\left(0, t_{n}\right), \\
& u_{n}=r
\end{aligned}
$$

untuk $r$ parameter bebas yang ada di rentang semua bilangan real. (Mencari $r$ yang konsisten dengan (2.14) akan diperoleh dengan mempergunakan metode shooting untuk menyelesaikan masalah syarat batas). 
Diketahui bahwa $u_{n}$ dan $v_{n}$ memiliki perwakilan berdasarkan metode variasi parameter:

$$
\begin{aligned}
& \left(\begin{array}{l}
v_{n} \\
u_{n}
\end{array}\right)=\Phi_{n}(x, 0)\left(\begin{array}{c}
-\alpha_{1}\left(t_{n}\right) r \\
0
\end{array}\right)+\Phi_{n}(x, 0)\left(\begin{array}{c}
\alpha\left(t_{n}\right) \\
0
\end{array}\right) \\
& +\int_{0}^{x} \Phi_{n}(x, y)\left(\begin{array}{c}
f\left(y, t_{n}\right)-\frac{c\left(y, t_{n}\right)}{\Delta t_{0}} u_{n-1}(y) \\
0
\end{array}\right) d y
\end{aligned}
$$

dengan $\Phi$ merupakan matriks fundamental yang memenuhi

$$
\Phi^{\prime}=\left(\begin{array}{cc}
-\hat{a}\left(x, t_{n}\right) & \hat{c}\left(x, t_{n}\right) \\
1 & 0
\end{array}\right) \Phi, \quad \Phi(y, y)=I
$$

dengan

$$
\hat{a}\left(x, t_{n}\right)=\frac{a\left(x, t_{n}\right)}{k\left(x, t_{n}\right)}, \quad \hat{c}\left(x, t_{n}\right)=\frac{c\left(x, t_{n}\right)}{\Delta t}-b\left(x, t_{n}\right) .
$$

Jika persamaan kedua di (2.16) diselesaikan untuk $r$, dan kemudian hasilnya disubstitusikan ke $v_{n}$, akan diperoleh hubungan berikut antara $u_{n}$ dan $v_{n}$ untuk setiap $r \in(-\infty, \infty)$

$$
v_{n}(x, r)=R_{n}(x) u_{n}(x, r)+w_{n}(x) .
$$

Bentuk ini tak lain merupakan transformasi Riccati untu persamaan diferensial orde 2. Karenanya haruslah berlaku untuk setiap $r$, bila dibandingkan ke (2.15) diperoleh

$$
R_{n}(0)=-\alpha_{1}\left(t_{n}\right) k\left(0, t_{n}\right), \quad w_{n}(0)=\alpha\left(t_{n}\right) k\left(0, t_{n}\right) .
$$

Karena $u_{n}$ dan $v_{n}$ memenuhi (2.13) dan $R_{n}$ dan $v_{n}$ merupakan kombinasi sederhana dari komponen $\Phi$ dan integral tentu di (2.16), bentuk (2.17) dapat diturunkan sehingga diperoleh

$$
v_{n}^{\prime}=R_{n}^{\prime} u_{n}+R_{n} u_{n}^{\prime}+w_{n}^{\prime}=R_{n}^{\prime} u_{n}+\frac{R_{n}\left(R_{n} u_{n}+w_{n}\right)}{k\left(x, t_{n}\right)}+w_{n}^{\prime} .
$$

Substitusikan persamaan diferensial untuk $v_{n}^{\prime}$ dan perwakilan (2.16) untuk $v_{n}$ dan kumpulkan semua suku yang memuat $u_{n}$, akan diperoleh

$$
\begin{aligned}
{\left[R_{n}^{\prime}\right.} & \left.+\frac{R_{n}^{2}}{k\left(x, t_{n}\right)}-\hat{c}\left(x, t_{n}\right)+\hat{a}\left(x, t_{n}\right) R\right] u_{n}(x, r) \\
& =\left[-w_{n}^{\prime}-\frac{R_{n} w_{n}}{k\left(x, t_{n}\right)}-\hat{a}\left(x, t_{n}\right) w_{n}+f\left(x, t_{n}\right)-\frac{c\left(x, t_{n}\right)}{\Delta t} u_{n-1}(x)\right] .
\end{aligned}
$$

Hubungan ini berlaku untuk setiap $r$ dan karena suku berkurungsiku bebas dari $r$, maka haruslah musnah. Sehingga akhirnya kita peroleh bahwa fungsi $R_{n}$ dan $w_{n}$ di transformasi Riccati (2.17) merupakan solusi masalah syarat awal berikut yang terdefinisi, yang dikenal sebagai 
persamaan invariant imbedding:

$$
\begin{aligned}
R_{n}^{\prime}= & \hat{c}\left(x, t_{n}\right)-\frac{R_{n}^{2}}{k\left(x, t_{n}\right)}-\hat{a}\left(x, t_{n}\right) R_{n} \\
R_{n}(0)= & -\alpha_{1}\left(t_{n}\right) k\left(0, t_{n}\right), \\
w_{n}^{\prime}= & -\left[\frac{R_{n}}{k\left(x, t_{n}\right)}+\hat{a}\left(x, t_{n}\right)\right] w_{n} \\
& +f\left(x, t_{n}\right)-\frac{c\left(x, t_{n}\right)}{\Delta t} u_{n-1}(x), \\
w_{n}(0)= & \alpha\left(t_{n}\right) k\left(0, t_{n}\right) .
\end{aligned}
$$

Perwakilan (2.17) harus dipenuhi pula untuk setiap $x$, jadi berlaku pula untuk batas bebas $s_{n}$. Sehingga $u_{n}\left(s_{n}\right)$ dan $s_{n}$ harus ditentukan sehingga

$H\left(u_{n}\left(s_{n}\right), \frac{R_{n} u_{n}\left(s_{n}\right)+w_{n}\left(s_{n}\right)}{k\left(s_{n}, t_{n}\right)}, \frac{u_{n}\left(s_{n}\right)-u_{n-1}\left(s_{n}\right)}{\Delta t}, s_{n}, \frac{s_{n}-s_{n-1}}{\Delta t}, t_{n}\right)=0$.

Dengan kata lain, batas bebas $s_{n}$ dan nilai $u_{n}\left(s_{n}\right)$, merupakan akar dari sistem dua persamaan:

$$
H\left(u, \frac{R_{n}(x) u+w_{n}(x)}{k\left(x, t_{n}\right)}, \frac{u-u_{n-1}(x)}{\Delta t}, x, \frac{x-s_{n-1}}{\Delta t}, t_{n}\right)=0 .
$$

Jika pasangan akar $\left(u_{n}, s_{n}\right)$ dapat ditemukan, maka (2.12) tereduksi menjadi masalah dua-titik biasa dengan syarat $v_{n}(0)=\alpha\left(t_{n}\right)-\alpha_{1}\left(t_{n}\right) u_{n}(0)$, dengan $u_{n}\left(s_{n}\right)$ ditentukan dari $(2.21)$, di interval $\left[0, s_{n}\right]$ yang tetap. Alternatif lain, $u_{n}$ dapat diperoleh dengan cara mengintegralkan transformasi Riccati (2.17):

$$
k\left(x, t_{n}\right) u_{n}^{\prime}=v_{n}=R_{n}(x) u_{n}+w_{n}(x),
$$

dengan $u_{n}\left(s_{n}\right)$ ditentukan dari (2.21), dengan cara mundur dari $s_{n}$ ke 0 . Pendekatan ini biasanya digunakan bila diselesaikan secara numerik. Lagi pula, seringkali mungkin mereduksi (2.21) dengan mengeliminasi salah satu $u$ ataukah $u_{x}$. Misalnya, hanya persamaan skalar yang perlu diselesaikan untuk masalah yang diperkenalkan di atas:

$$
\begin{aligned}
\phi_{n}= & \frac{R_{n}(x) u_{n}(x)+w_{n}(x)}{k\left(x, t_{n}\right)}+\lambda \frac{x-s_{n-1}}{\Delta t}+\mu_{2}\left(x, t_{n}\right) \\
= & R_{n}(x)\left(-\mu_{1}\left(x, t_{n}\right)\right)+w_{n}(x) \\
& +\left[\lambda \frac{x-s_{n-1}}{\Delta t}+\mu_{2}\left(x, t_{n}\right)\right] k\left(x, t_{n}\right)=0 ;
\end{aligned}
$$

(ii) $\phi_{n}(x)=w_{n}(x)=0$;

(iii) $\phi_{n}=-R_{n}(x) \mu_{1}\left(x, t_{n}\right)+w_{n}(x)+\mu_{2}\left(x, t_{n}\right) k\left(x, t_{n}\right)=0$;

$$
\begin{aligned}
& \phi_{n}=R_{n}(x) \cdot \mu_{1}\left(x, t_{n}\right) e^{\mu_{2} / x}+w_{n}(x) \\
& -\left[\mu_{3}-\mu_{1}\left(x, t_{n}\right) e^{\mu_{2} / x}\right] \frac{x-s_{n-1}}{\Delta t} k\left(x, t_{n}\right)=0 ; \\
& \text { (v) } \phi_{n}=R_{n}(x) \psi_{n}(x)+w_{n}(x)-\mu_{1}\left(\psi_{n}^{4}-\mu_{2}^{4}\right) \cdot k\left(x, t_{n}\right)=0 \text {; } \\
& \text { dengan } \psi_{n}(x)=\mu_{5}-\mu_{4} /\left(\ln \left(\left(x-s_{n-1}\right) / \Delta t\right)-\ln \mu_{3}\right) \text {. }
\end{aligned}
$$

Jadi, untuk setiap masalah yang diperkenalkan di atas, pendekatan yang sama dapat digunakan. Persamaan invariant imbedding (2.19) dan (2.20) diintegrasikan maju dalam variabel $x$ dan fungsional $\phi(x)$ 
dievaluasi. Bila memotong sumbu- $x$ batas bebas $s_{n}$ ditetapkan dan $u_{n}\left(s_{n}\right)$ ditentukan dari (2.21), yang memungkinkan menghitung $u_{n}$ sepanjang $\left[0, s_{n}\right]$ misalnya dengan cara mengintegralkan (2.22). Dari sini jelaslah bahwa langkah langkah tersebut di atas dapat diselesaikan secara numerik.

\section{Kekonvergenan Metode Rothe}

Untuk mendemonstrasikan bagaimana teknik solusi di atas dapat digunakan untuk memperoleh bukti eksistensi, tinjau masalah model berikut,

$$
\begin{aligned}
u_{x x}-u_{t} & =f(x, t), \\
u(0, t) & =\alpha(t), \\
u(s(t), t) & =0 \\
u_{x}(s(t), t) & =0 \\
u(x, 0) & =0 \\
s(0) & =0
\end{aligned}
$$

Sebagaimana dikatakan, masalah jenis ini muncul di teori optimal stopping, dengan $u$ berkait dengan fungsi imbalan (reward function/value function) terkait dengan satu proses Brown dan $s(t)$ merupakan batas penghentian optimum dari proses (Lihat [35] dan rujukan yang dikutip).

Persamaannya cukup sederhana tetapi menonjolkan aspek matematis yang cukup pentingkarena bukti keujudan solusi metode garis sebelumnya memustahilkan musnahnya gradien di batas bebas [35], [38]. Sehingga, beberapa hasil di [19] cukup berbeda secara signifikan dibanding literatur lainnya. Kita akan tunjukan secara berurutan bahwa berdasarkan sejumlah hipotesis:

i) persamaan metode garis untuk (3.1) memiliki solusi di setiap tingkat waktu diskret;

ii) bahwa $u_{n}, u_{n}^{\prime},\left(u_{n}-u_{n-1}\right) / \Delta t$, dan $\left(s_{n}-s_{n-1}\right) / \Delta t$ terbatas seragam;

iii) penyelesaian yang terkait (3.1) yang didefinisikan dalam $\left(u_{n}, s_{n}\right)$ konvergen ke sebuah solusi dari (3.1).

Dua alat utama yang penting digunakan secara berulang, yaitu prinsip maksimum untuk persamaan diferensial (eliptik) biasa (lihat misalnya [29]) dan teorema Ascoli mengenai kekompakan barisan terbatas seragam dari fungsi ekikontinu (lihat misalnya [31]). 
Hampiran metode Rothe untuk masalah batas bebas (3.1) ialah:

$$
\begin{aligned}
& u_{n}^{\prime \prime}-\left(u_{n}-u_{n-1}\right) / \Delta t=f\left(x, t_{n}\right), \\
& n=1, \cdots, N, \Delta t=T / N \text {, } \\
& \text { atau } \\
& \begin{aligned}
v_{n}^{\prime}= & u_{n} / \Delta t+f\left(x, t_{n}\right) \\
& -u_{n-1} / \Delta t, \quad v_{n}(0)=\alpha\left(t_{n}\right), \\
u_{n}^{\prime}= & v_{n}, \quad u_{n}\left(s_{n}\right)=v_{n}\left(s_{n}\right)=0, \\
u_{0}= & 0,
\end{aligned}
\end{aligned}
$$

Persamaan invariant imbedding yang terkait ialah

$$
\begin{aligned}
v_{n}^{\prime}= & R(x) u_{n}(x)+w_{n}(x), \\
R(x)= & \frac{1}{\Delta t}-R(x)^{2}, \quad R(0) \\
w_{n}^{\prime}= & -R(x) w_{n}+f\left(x, t_{n}\right)-u_{n-1} / \Delta t, \\
& w_{n}(0)=\alpha\left(t_{n}\right),
\end{aligned}
$$

dan batas bebas yang ditentukan sebagai akar $s_{n}$ dari persamaan

$$
\phi_{n}(x)=w_{n}(x)=0 .
$$

Untuk membuktikan keujudan solusi $\left(u_{n}, s_{n}\right)$ di setiap tingkat waktu diskret $n$ dan kekonvergenan diperlukan hipotesis berikut ini.

H.1. $\alpha(t) \leq 0, t \in(0, T]$; terdapat fungsi kontinu $C$ dan $c$ sehingga $C(t) \geq f(x, t) \geq c(t) \geq c>0,(x, t) \in(0, \infty) \times[0, T]$.

H.2.i. Terdapat konstanta Lipschitz $L_{i} \geq 0, i=1,2,3$, sehingga

$$
\begin{aligned}
0 \geq \alpha(t)-\alpha(r) & \geq L_{1}(r-t), & t, r & \in(0, T] \\
0 \geq f(x, t)-f(x, r) & \geq L_{2}(r-t), & t, r & \in(0, T], \text { seragam di } x, \\
\left|\frac{\partial f}{\partial x}(x, t)-\frac{\partial f}{\partial x}(x, r)\right| & \geq L_{3}(r-t), & t, r & \in(0, T], \text { seragam di } x .
\end{aligned}
$$

H.2.ii. Terdapat syarat batas yang konsisten sehingga $\alpha(0)=0$.

Keujudan solusi ditunjukan lema berikut,

Lema 3.1. Dengan hipotesis H.1., solusi metode Rothe $\left\{u_{n}, s_{n}\right\}$ ada untuk setiap $n=1, \cdots, N$.

Bukti 3.2. Untuk lengkapnya lihat di [19].

Untuk menunjukan kekonvergenan bersamaan dengan $\Delta t \rightarrow 0$, harus ditunjukan bahwa batas bebas yang dihitung $\left\{s_{n}\right\}_{n=0}^{N}$ dapat digunakan untuk mendefinisikan batas $s(t)$ yang kontinu Lipschitz bersamaan dengan $\Delta t \rightarrow 0$. Satu taksiran berbentuk

$$
\left|s_{n}-s_{n-1}\right| \leq K \Delta t
$$


cukup untuk tujuan ini yang dengan mudah diperoleh dari uraian Taylor

$u_{n}\left(s_{n-1}\right)=u_{n}\left(s_{n}\right)+u_{n}^{\prime}\left(s_{n}\right)\left(s_{n}-s_{n-1}\right)+\frac{1}{2} u_{n}^{\prime \prime}(\zeta)\left(s_{n}-s_{n-1}\right)^{2}, \quad \zeta \in\left(s_{n-1}, s_{n}\right)$

dengan membatasi $u_{n}\left(s_{n-1}\right)$ dari atas dan $u_{n}^{\prime \prime}(\zeta)$ dari bawah. Anggapan bahwa asumsi hipotesis H.1. dan H.2. berlaku.

Lema 3.3. Syarat kemonotonan berikut berlaku

$$
u_{n}(x) \geq u_{n-1}(x) \geq 0, \quad s_{n} \geq s_{n-1} .
$$

Bukti 3.4. Lihat di [19].

Untuk masalah Stefan dan filtrasi, suku $u_{n}^{\prime}\left(s_{n}\right)$ tidaklah musnah, dan karenanya cukup diturunkan batas berbentuk $u_{n}^{\prime}\left(s_{n-1}\right) \leq K \Delta t$ di uraian Taylor di atas (lihat [18] dan [38]). Untuk (3.2) di atas, batas berbentuk $\left|u_{n}^{\prime}\left(s_{n-1}\right)\right| \leq K \Delta t\left(s_{n}-s_{n-1}\right)$ merupakan hal perlu. Kita akan trunkan dengan membatasi $\left|u_{n}^{\prime}\right|$ dengan $K \Delta t$ di $\left[s_{n-1}, s_{n}\right]$. Lema berikut diperlukan untuk bukti hasil tersebut. Bukti lema dan Teorema dapat di lihat di [19].

Lema 3.5. Terdapat sebuah konstanta $K$ sehingga $\left|u_{n}^{\prime}-u_{n-1}^{\prime}\right| \leq K \Delta t$ di $\left[0, s_{n}\right]$.

Teorema 3.1. Dengan hipotesis H.1. dan H.2., terdapat satu konstanta $K$ yang bebas dari $\Delta t$ sehingga

$$
s_{n+1}-s_{n} \leq K \Delta t \text {. }
$$

Dari Teorema tersebut, dapat diperoleh hasil $s_{n} \leq K T$ untuk suatu $K$ yang konstan, sehingga dengan demikian kita perlu hanya memperhatikan masalah (3.2) di $[0, \tilde{X}]$ untuk $\tilde{X}=K T$. Lebih jauh dengan memanfaatkan lema 3.5 sebelum ini, diperoleh $\left|u_{n}(x)-u_{n-1}(x)\right| \leq$ $K \Delta t\left|s_{n}-x\right|$, sehingga

$$
\left|\frac{u_{n}(x)-u_{n-1}(x)}{\Delta t}\right| \leq K
$$

seragam di $x$ dan $n$ untuk setiap $x \in[0, \tilde{X}]$.

Solusi aproksimasi metode Rothe $\left(u_{n}, s_{n}\right)$ dapat digunakan untuk membuktikan solusi pendekatan masalah batas bebas (3.1). Tetapkan

$$
\begin{aligned}
S_{N}(t) & =\frac{1}{\Delta t}\left\{\left(t-t_{n-1}\right) s_{n}+\left(t_{n}-t\right) s_{n-1}\right\}, \\
U_{N}(t) & =\frac{1}{\Delta t}\left\{\left(t-t_{n-1}\right) u_{n}+\left(t_{n}-t\right) u_{n-1}\right\} .
\end{aligned}
$$

Dengan mempergunakan teorema Ascoli, dapat ditunjukkan terdapat anak barisan $\left\{N_{l}\right\}$ sedimikian rupa sehingga $S_{N_{l}}$ dan $U_{N_{l}}$ konvergen secara seragam ke fungsi limit $s(t)$ dan $u(x, t)$ yang kontinu Lipschitz. 
Untuk menunjukkan bahwa $s(t)$ dan $u(x, t)$ menyelesaikan masalah (3.1), untuk kemudahan perlu diperkenalkan konsep solusi lemah untuk masalah batas bebas.

Definisi 3.6. Solusi lemah masalah syarat batas (3.1) ialah sebuah fungsi u yang terukur dan terbatas serta fungsi s yang kontinu dengan $s(0)=0$, yang untuk fungsi sebarang $\phi \in D$ dipenuhi

$$
\int_{0}^{T} \int_{0}^{s(t)}\left[\left(\phi_{x x}-\phi_{t}\right) u-f \phi\right] d x d t-\int_{0}^{T} \phi(0, t) \alpha(t) d t .
$$

Dengan $D$ menyatakan ruang fungsi uji. Ruang fungsi uji $D$ terdiri atas fungsi dua variabel yang terdefinisi di $[0, \tilde{X}] \times[0, T]$ yang terturunkan 2 kali di $x$ dan sekali di $t$ di $[0, \tilde{X}] \times[0, T]$ dan berlaku $\phi(x, T)=\phi_{x}(0, t)$.

Dengan mempergunakan konsep solusi lemah ini, dapat ditunjukkan mengenai keujudan solusi. Sebagaimana dimanfaatkan dalam menunjukkan keujudan solusi dalam persamaan panas pada batas yang tetap, bahwa solusi lemah yang cukup licin merupakan syarat kecukupan untuk ujudnya solusi klasik, hal yang sama dapat diperluas untuk kasus batas bebas. Kemudian, dapat diperlihatkan ketunggalan solusi lemah. Untuk diskusi rinci mengenai hal ini lihat di [19]. Teorema berikut menunjukkan bahwa solusi akan konvergen ke solusi klasik yang tunggal.

Teorema 3.2. Dengan hipotesis H.1., H.2., solusi metode garis yang didefinisikan oleh (3.12) konvergen secara seragam ke sebuah solusi klasik yang tunggal dari masalah syarat batas bebas (3.1).

Bukti 3.7. Rincian pembuktian dapat dilihat di [19].

\section{Contoh.}

4.1. Optimal Stopping. Masalah batas bebas berikut ini bermula dari teori optimal stopping sebagaimana dibahas oleh [35]

$$
\begin{aligned}
u_{x x}-u_{t} & =0 \\
u_{x}(0, t) & =\frac{1}{2} \\
u(s(t), t) & =\frac{1}{2 t}, \quad u_{x}(s(t), t)=0, \quad s(0)=0
\end{aligned}
$$

Meski tidak diketahui mengenai hasil analitik yang menunjukkan keujudan solusi untuk masalah singular ini, dapat ditunjukkan bahwa satu solusi aproksimasi $\left(u_{n}, s_{n}\right)$ dapat dihitung dengan mempergunakan metode Rothe dari masalah batas bebas yang berkaitan.

Jika didefinisikan

$$
w=\frac{1}{2 t}-u
$$


maka $w$ akan memenuhi masalah batas bebas implisit

$$
\begin{aligned}
w_{x x}-w_{t} & =\frac{1}{2 t^{2}} \\
w_{x}(0, t) & =-\frac{1}{2} \\
w(s(t), t) & =w_{x}(s(t), t)=0, \quad s(0)=0 .
\end{aligned}
$$

Karena data singular di $(x, t)=(0,0)$, teori di atas tidak berlaku. Akan tetapi dengan melicinkan data dengan cara

$$
\begin{gathered}
f_{\varepsilon}(x, t)= \begin{cases}\frac{1}{2 \varepsilon^{2}}, & t \in[0, \varepsilon], \\
\frac{1}{2 t^{2}}, & t>\varepsilon,\end{cases} \\
\alpha_{\varepsilon}(x, t)= \begin{cases}-\frac{1}{2 \varepsilon}, & t \in[0, \varepsilon], \\
-\frac{1}{2}, & t>\varepsilon,\end{cases}
\end{gathered}
$$

kita tinjau

$$
\begin{aligned}
w_{x x}-w_{t} & =f_{\varepsilon}(x, t) \\
w_{x}(0, t) & =\alpha_{\varepsilon}(t) \\
w(s(t), t) & =w_{x}(s(t), t)=0, \quad s(0)=0 .
\end{aligned}
$$

Untuk $\varepsilon$ yang tetap, fungsi $f_{\varepsilon}$ dan $\alpha_{\varepsilon}$ memenuhi hipotesis $H .1$. dan $H .2$, sehingga untuk $\varepsilon>0$ penyelesaian $w$ memiliki solusi dan tunggal.

Jika kita selesaikan secara numerik, kita peroleh bahwa persamaan Riccati memiliki solusi eksak

$$
R(x)=\frac{1}{\sqrt{\Delta t}} \tanh \frac{x}{\sqrt{\Delta t}},
$$

sementara persamaan (2.20) dan (2.22) diintegralkan secara numerik. Batas bebas $s_{n}$ di tingkat waktu diskret ke- $n$ merupakan akar dari $w_{n}(x)=0$ dan dapat diperoleh dengan mempergunakan interpolasi linear di antara dua titik kisi berturutan di mana $w_{n}$ berganti tanda.

Kasus $\varepsilon=0$ merupakan kasus yang menarik, barisan $\left\{w^{\varepsilon}(x, t), s^{\varepsilon}(t)\right\}$ dihitung dengan mengambil $\varepsilon=\Delta t$ (yaitu dengan mengabaikan singularitas data). Hasil numerik metode Rothe dibandingkan dengan hasil [35] untuk posisi batas bebas dapat di lihat di [19].

4.2. Opsi Jual Amerika (American Put Option). Valuasi opsi Amerika atas saham dengan imbalan $\psi$ dan jatuh tempo $T$ dapat dinyatakan sebagai $V(S, 0)$ dengan $S(0)=S$ dan $V(S, t)$ merupakan solusi dari masalah batas bebas berikut. Khususnya untuk kasus Opsi Jual Amerika, untuk setiap $t>0$ terdapat $s^{*}(t)$ yang tunggal sehingga: 


$$
\begin{aligned}
& \frac{1}{2} \Sigma(s, t)^{2} \frac{\partial^{2} V}{\partial s^{2}}(s, t)+[r(t)-\rho(t)] s \frac{\partial V}{\partial s}(s, t) \\
& -r(s, t) V(s, t)=-\frac{\partial V}{\partial t}(s, t), \\
& s \in\left(s^{*}, \infty\right), t \in[0, T), \\
& V(S, t) \rightarrow(\kappa-s)^{+}, \quad t \rightarrow T, \\
& V(S, t) \rightarrow 0, s \rightarrow \infty, \\
& t \in[0, T), \\
& V(S, t)>(\kappa-s)^{+}, \\
& s \in\left(s^{*}, \infty\right) \text {, } \\
& t \in[0, T), \\
& V(S, t) \rightarrow\left(\kappa-s^{*}(t)\right), s \rightarrow s^{*}(t)+, \\
& t \in[0, T), \\
& \frac{\partial V}{\partial t}(S, t)=-1, s \rightarrow s^{*}(t)+, \\
& t \in[0, T) \text {. }
\end{aligned}
$$

Jika dilakukan normalisasi

$$
u=V / \kappa, \quad x=s / \kappa,
$$

dan untuk kemudahan, gunakan variabel waktu yang baru

$$
\tau=T-t
$$

Maka diperoleh masalah batas bebas:

$$
\begin{aligned}
\frac{1}{2} \sigma(x, \tau) \frac{\partial^{2} u}{\partial x^{2}}(x, \tau)+ & \\
b(x, \tau) \frac{\partial u}{\partial x}(x, \tau)-r(x, \tau) u(x, \tau) & =-\frac{\partial u}{\partial \tau}(x, \tau) \\
& x \in(s(\tau), \infty), \tau \in(0, T],(s(\tau), \quad 0<\tau \leq T \\
\frac{\partial u}{\partial x}(s(\tau)+, \tau) & =-1, \tau \in(0, T] \\
u(x, \tau) & \rightarrow 0, x \rightarrow \infty, \tau \in(0, T] \\
u(x, \tau) & =0, x \in(s(0)=1, \infty)
\end{aligned}
$$

Hampiran Rothe untuk setiap tingkat waktu- $n$ :

$$
\sigma\left(x, \tau_{n}\right) u_{n}^{\prime \prime}+b\left(x, \tau_{n}\right) u_{n}^{\prime}-r\left(x, \tau_{n}\right) u_{n}-\frac{u_{n}-u_{n-1}}{\Delta \tau}=0,
$$

Atau, jika ditulis secara umum:

$$
u_{n}^{\prime \prime}+d\left(x, \tau_{n}\right) u_{n}^{\prime}-c\left(x, \tau_{n}\right) u_{n}=g\left(x, \tau_{n}\right),
$$


Sehingga kita peroleh sistem persamaan diferensial orde-1:

$$
\begin{aligned}
& u_{n}^{\prime}=v_{n} \\
& v_{n}^{\prime}=c\left(x, \tau_{n}\right) u_{n}-d\left(x, \tau_{n}\right) v_{n}+g\left(x, \tau_{n}\right),
\end{aligned}
$$

Dengan mempergunakan transformasi Riccati,

$$
u(x)=R(x) v(x)+w(x)
$$

diperoleh persamaan invariant imbedding,

$$
\begin{aligned}
& R^{\prime}=1+d\left(x, \tau_{n}\right) R-c\left(x, \tau_{n}\right) R^{2}, \quad R(X)=0 \\
& w^{\prime}=-c\left(x, \tau_{n}\right) R(x) w-R(x) g\left(x, \tau_{n}\right), \quad w(X)=h\left(\tau_{n}\right) .
\end{aligned}
$$

dengan $[0, X]$ pemenggalan dari interval tak hingga $[0, \infty)$, dengan $h\left(\tau_{n}\right)$ akan ditentukan kemudian. Dengan mengintegralkan secara mundur persamaan invariant imbedding, kemudian kita peroleh batas bebas $s_{n}$ dengan mencari akar dari:

$$
\phi(x)=R(x)-w(x)+(1-x) .
$$

Jika batas bebas $s_{n}$ sudah diketahui, integralkan

$$
v_{n}^{\prime}=c\left(x, \tau_{n}\right)\left(R(x) v_{n}+w(x)\right)-d\left(x, \tau_{n}\right) v_{n}+g\left(x, \tau_{n}\right), \quad v_{n}\left(s_{n}\right)=-1,
$$

sepanjang selang $\left[s_{n}, X\right]$. Kemudian substitusikan ke transformasi Riccati, untuk mendapatkan $u_{n}$. Solusi diperluas ke selang $\left(s_{\infty}, s_{n}\right)$ dengan mempergunakan fungsi linear.

\section{Penutup.}

Penggunaan metode garis lateral yang tidak terkait dengan persamaan panas atau kah memiliki bentuk khusus dari data batas pada batas yang tetap mau pun batas bebas, disajikan dalam tulisan [19] bagaimana teknik penyelesaiannya.

\section{REFERENCES}

[1] J.G. Andrews \& D.R. Athey, Drilling Holes with a Laser, dalam J.G. Andrew\& R.R. McLone (ed), Mathematical Modelling., Butterworths, 1976.

[2] T. Araki, Y. Sagara, K. Abdullah \& A.H. Tambunan, Transport properties of cellular Food Materials undergoing Freeze-Drying, Drying Technology, 19(2), 2001, 297-312

[3] T. Araki, Y. Sagara, A.H. Tambunan \& K. Abdullah, Measurement of Transport Properties for the Dried Layer of Several Food Materials ,Bull.Keteknikan Pertanian, 12(2), 2xxx, p-ppp

[4] R.D. Bachelis, V. G. Melamed \& D.S.Shlyaver, The solution of the problem of Stefan type by the straight line method, Zh.Vycisl.Mat. Fiz., v9, pp 585-594.

[5] I.Berezin \& N.Zhidkov, Computing Methods, vol. II., Pergamon Press., Oxford, England, 1965.

[6] A. Bossavit, A. Damlamian, \& M. Fremond (eds), Free Boundary Problems: Applications and Therory. Vol IV, Pitman, 1985.

[7] Y. Chuang \& O.Ehrich, On the integral technique for spherical growth problems, Int.J. Heat Mass Transfer, 17, 1974, 945-953. 
[8] J. Crank \& R.S. Gupta, A method for solving moving boundary problems in heat flow using cubic splines or polynomials, J. Inst. Math. Appl., 1972, 296-304.

[9] M. Farid, The moving boundary problems from melting and freezing to drying and frying of food, Chem. Eng. Proc., 41, 2002, 1-10.

[10] A.D. Garnadi, Approximate Solution of nonlinear boundary value problems of Heat Conduction for simulation of freeze drying. (Constant Temperatures Heat Source), Manuskrip.

[11] A.D. Garnadi, Approximate Solution of nonlinear boundary value problems of Heat Conduction for simulation of freeze drying. (Linearized Radiation Boundary Condition), Manuskrip.

[12] A.D. Garnadi, A Ubiquitous Lambert W-functions, (Notes on Messinger Model of Ice accretion on aircraft structures), Manuskrip.

[13] D.W.Goodwin, Lasers in Surgery, Phys.Technol., 9, 1978, 248-253.

[14] A. Hollis, S. Rastegar, L. Descloux, G. Delacretaz, \& K. Rink, Zona Pellucida Microdrilling with a $1.48 \mu \mathrm{m}$ diode laser, IEEE Engineering in Med. Biol., May/June 1997, 43-47.

[15] S. Kruzhov, On Some problems with unknown boundaries for the heat equation, Prikl. Math. Meh., 31 (1967), 1009-1020.

[16] U.A. Ladyzhenskaya, V.A. Solonnikov \& N.N. Uraltseva, Linear and Quasilinear Equations of Parabolic Type, American Mathematical Society, Providence, R.I., 1968.

[17] G.H. Meyer, Initial Value Methods for Boundary Value Problems, Academic Press

[18] G.H. Meyer, On a free interface problem for linear ordinary differential equations and the one phase Stefan problem, Numer. Math., 16, (1970), pp 248-267.

[19] G.H. Meyer, One-dimensional parabolic free boundary problems, SIAM Review, 19, (1977), 17-34.

[20] G.H. Meyer, Heat transfer during fluidized-bed coating, Int. J. Numer. Meth. in Engrg.

[21] G.H. Meyer, The method of lines, line SOR and Free Boundaries, dalam K.I. Gross(ed), Mathematical Methods in Energy Research, SIAM, 1985, 59-74.

[22] G.H. Meyer, On Pricing American and Asian Options with PDE Methods, Acta. Math. Univ. Commenianae, LXX(1), 2001, 153-165.

[23] G.H. Meyer \& J. van der Hoek, The valuation of American Option with the Method Lines, Adv. Futures Options Res., 9, (1997), 265-285.

[24] W.J. Meyer, H.U. Akay, \& M.J. Pikal, A computational model for finite element analysis of the freeze drying process, 148, 1977, 105-124.

[25] T.G. Myers, D.W. Hammond., Ice and water film growth from incoming supercooled droplets., Int. J. Heat Mass Transf., 42 (1999),2233-2242.

[26] J.R. Ockendon \& W.R. Hodgkins (eds), Moving Boundary Problems in Heat Flow and Diffusion, Clarendon Press, Oxford, England, 1975.

[27] J.A. Puente, G. Lambrinos, \& M. Sakly, Sublimation of ice and frozen dispersed media : physical phenomena, equations and experimental study, dalam, [6], 305-317.

[28] S. Rastegar, M. Motamedi, A.J. Welch, \& L.J. Hayes, A Theoretical Study of the effect of optical properties in Laser Ablation of Tissue., IEE Trans. Biomed. Eng., 36(12), 1989, 1180-1187.

[29] H.M. Protter \& H.F. Weinberger, Maximum Principles in Differential Equations, Prentice-Hall, Englewood-Cliffs, N.J., 1967.

[30] E. Rothe, Zweidimensionale parabolische Randwertaufgaben als Grenzfall eindimensionaler Rasndwertaufgaben, Math.Ann., 102, (1929/30), 650-670. 
[31] H.L. Royden, Real Analysis, MacMillan, London, 1978.

[32] L.I. Rubinstein, The stefan problem, Transl. Math. Monographs, vol 27, American Matemathical Society, Providence, R.I., 1971.

[33] A. Sachs, Zur Struktur eines Algorithms zur Lösung freier Randwertprobleme parabolischer Differentialoperatoren, Lecture Notes in Math., vol 395, Springer-Verlag, Berlin, 1974.

[34] G.G. Sackett, An implicit free boundary value problem for the heat equation, SIAM J. Numer. Anal., 8, 1971, 80-95.

[35] G.G. Sackett, Numerical Solution of a parabolic free boundary problem arising in statistical decision theory., Math. Comp., 25, 1971, 425-434.

[36] N.L. Schryer, Designing Software for one-dimensional Partial Differential Equations, ACM Trans.On Math.Soft., 16(1), 1990, 72-85.

[37] F.P. Vasilev, the method od straight lines for the solution of a one phase problem of the stefan type, Z. Vycisl. Mat. i. mat. Fiz., 8, 1968, 64-78.

[38] T.D. Wentzel, A free boundary problem for the heat equation, Dokl. Akad. Nauk. SSSR, 131, 1960, 1000-1003.

[39] P. Wilmot, S. Howison, \& J. Dewynne, 1995, The Mathematics of Financial Derivatives, Cambridge Univ. Press. 


\section{BAB 2. Metode Garis Lateral untuk Pindah Panas Dalam Proses Pasca Panen}

Persamaan diferensial parsial parabolik, merupakan salah satu dari sekian banyak persamaan differensial yang sangat berperan dalam memodelkan berbagai masalah yang timbul dari ragam fenomena di sekitar kita. Meskipun beberapa persamaan panas yang tergolong sederhana dapat dicari solusi eksaknya, namun banyak permasalahan yang dimodelkan dalam persamaan panas dimana solusi eksak sulit dicari atau bahkan sama sekali tidak memiliki solusi eksak. Alternatifnya, bila solusinya ada dan tidak dapat diperoleh secara eksak, adalah dengan menyelesaikan persamaan panas tersebut secara numerik. Untuk itu dibutuhkan rutin (program) yang mampu menyelesaikan Persamaan Differensial Parsial (PDP) secara numerik. Namun hingga saat ini sedikit sekali perangkat lunak numerik yang menyediakan rutin untuk keperluan ini. Di lain pihak, rutin-rutin yang mampu menyelesaikan Persamaan Differensial Biasa (PDB) telah banyak berkembang dan sudah menjadi paket yang sudah jadi di hampir setiap perangkat lunak numerik yang ada saat ini.

Tujuan tulisan ini menyajikan tutorial yang menunjukkan teknik penyelesaian persamaan panas secara numerik dengan memanfaatkan rutin numerik untuk menyelesaikan Masalah Syarat Batas (MSB) untuk PDB. Rutin yang digunakan adalah rutin yang tersedia di dalam SCILAB yang bernama bvode. Untuk tutorial penggunaan serta keterangan mengenai bvode dapat dilihat pada [4, Garnadi dkk, 2015]. Salah satu metode untuk menyelesaikan secara numerik persamaan evolusi, dikenal dengan metode garis ([8,Madsen dan Sincovec, 1979; 9, May, 1990]). Metode ini dilakukan dengan cara melakukan diskretisasi ruang dengan mempergunakan beda hingga ([9, May, 1990]) atau kolokasi ([8, Madsen dan Sincovec, 1979; 12, Skeel dan Berzins, 1990]) misalnya, sehingga diperoleh sebuah masalah nilai awal untuk sebuah sistem PDB. Kemudian, dapat digunakan berbagai rutin numerik yang tersedia untuk menyelesaikan sistem PDB tersebut. Di dalam PSE komersial MATLAB disediakan pdepe untuk menyelesaikan persamaan parabolik 1-dimensi spasial, rutin ini didasarkan pada ([12, Skeel dan Berzins, 1990]) yang mempergunakan metode kolokasi untuk diskretisasi ruang. Pendekatan lain untuk menyelesaikan persamaan diferensial parsial evolusi ialah menggunakan strategi diskretisasi waktu terlebih dulu, sehingga diperoleh MSB PDB untuk 
1 setiap langkah waktu. Dengan demikian, secara bertingkat diselesaikan secara berturutan harus

2 diselesaikan MSB PDB. Teknik seperti ini sering sekali dikenal sebagai metode garis lateral,

3 atau dikenal juga dengan metode Rothe. Dalam [7, Garnadi, 2004], terdapat ulasan singkat

4 mengenai metode garis lateral ini. Salah satu tujuan tulisan ini ialah sebagai tutorial

5 penggunaan perangkat lunak numerik untuk menyelesaikan persamaan diferensial parabolik

6 secara umum. Tujuan lain dari tulisan ini ialah mendukung Indonesian Goes Open Source

7 (IGOS) di bidang Scientific Computing, mengingat SCILAB merupakan perangkat lunak yang

8 bebas. Selain itu, tulisan ini sebagai langkah awal penyediaan perangkat alternatif dari

9 perangkat lunak komersial MATLAB yang cukup populer, dimana tersedia pdepe. Tulisan ini

10 disusun seperti berikut ini, pertama akan diingatkan terkait dengan persamaan panas.

11 Kemudian secara singkat akan diperlihatkan diskretisasi waktu, sehingga diperoleh bentuk

12 masalah syarat batas PDB untuk setiap langkah waktu diskret. Dengan demikian, bentuk ini

13 dapat dikonversikan sehingga dapat diselesaikan dengan mempergunakan bvode dalam

14 SCILAB. Dilanjutkan dengan bagian berikutnya yang memperlihatkan susunan lengkap

15 implementasi metode garis lateral untuk menyelesaikan persamaan panas dan aplikasinya

16 dalam SCILAB.

Pada makalah ini akan dibahas penyelesaian persamaan panas satu dimensi dengan

22 menggunakan metode garis lateral dengan dua ilustrasi, yaitu persamaan panas dalam batang

23 dan model perlakuan panas buah untuk disinfestasi serangga. Ilustrasi pertama, bersifat

24 pedagogis, sementara ilustrasi kedua berupa aplikasi untuk simulasi disinfestasi serangga pada 25 buah.

\section{Persamaan Panas Pada Batang.}

29 Jika pada waktu $t=0$ sebuah batang konduktor termal, selanjutnya kita katakan konduktor,

30 dengan panjang $\mathrm{L}$ memiliki suhu yang terdistribusi menurut rumus $Q_{0}=u_{0}(x)$, maka setelah

31 beberapa saat suhu di batang tersebut akan terdistribusi pada batang konduktor menurut 32 persamaan 
$1 \quad \frac{\partial u(t, x)}{\partial t}=C \frac{\partial^{2} u(t, x)}{\partial x^{2}}$,

$$
0 \leq x \leq L, t \geq 0
$$

2 Sebagai tambahan, untuk $t \geq 0$, jika batang konduktor tersebut dipanasi atau didinginkan

3 akibat adanya sumber panas $Q_{\text {eksternal }}=f(t, x)$, maka persamaan (1) akan menjadi

$$
\begin{gathered}
\frac{\partial u(t, x)}{\partial t}=C \frac{\partial^{2} u(t, x)}{\partial x^{2}}+f(t, x), \\
0 \leq x \leq L, t \geq 0
\end{gathered}
$$

5 Persamaan (1) dan (2) dikenal dengan nama persamaan panas dimana $C$ adalah diffusivitas

6 termal benda yang dipanasi. Bersama dengan nilai-nilai awal yang diketahui, persamaan (1)

7 dan (2) merupakan masalah syarat batas

$$
\frac{\partial u(t, x)}{\partial t}=C \frac{\partial^{2} u(t, x)}{\partial x^{2}}+f(t, x)
$$

$$
\begin{aligned}
& 0 \leq x \leq L, t \geq 0 ; \\
& u(x, 0)=u_{0}(x), u(t, 0)=u_{a}, u(t, L)=u_{b} .
\end{aligned}
$$

9 dengan $u_{a}$ dan $u_{b}$ masing-masing menyatakan suhu pada ujung-ujung batang konduktor 10 tersebut.

11 Dengan metode diskretisasi waktu, selang $t$ yang kontinu digantikan oleh titik-titik diskrit

12 yang membentuk mesh. Turunan waktu yang ada pada persamaan (3) dihampiri dengan beda

13 hingga (finite difference), sehingga persamaan (3) menjadi

$$
\frac{u^{k+1}(x)-u^{k}(x)}{\Delta t}=C \frac{d^{2} u^{k+1}(x)}{d x^{2}}+f^{k+1}(x)
$$

$$
\begin{aligned}
& 0 \leq x \leq L, k=0,1,2, \ldots ; \\
& u^{0}(x)=u_{0}(x), u^{k+1}(0)=u_{a}, u^{k+1}(L)=u_{b} .
\end{aligned}
$$

15 Dengan menyusun kembali penulisannya, persamaan (4) akan menjadi

$$
\frac{d^{2} u^{k+1}(x)}{d x^{2}}=\frac{1}{C} \frac{u^{k+1}(x)-u^{k}(x)}{\Delta t}-f^{k+1}(x)
$$

$$
\begin{aligned}
& 0 \leq x \leq L, k=0,1,2, \ldots ; \\
& u^{0}(x)=u_{0}(x), u^{k+1}(0)=u_{a}, u^{k+1}(L)=u_{b} .
\end{aligned}
$$

Perhatikan bahwa persamaan (5) merupakan masalah syarat batas dari persamaan differensial

19 biasa orde 2 yang dapat dicari solusi numeriknya menggunakan bvode untuk setiap langkah

20 waktu ke $k$. Dengan demikian, akibat diskretisasi pada langkah waktu, memungkinkan

21 penggunaan bvode untuk mencari solusi numerik MSB, sehingga untuk setiap langkah waktu

22 diperoleh profil distribusi panas. 


\section{Model perlakuan panas buah untuk disinfestasi serangga}

3 Di negara yang beriklim tropis seperti Indonesia ini, petani buah banyak dihadapi pada 4 masalah pasca panen yaitu serangan hama larva serangga seperti ulat atau pun kutu. 5 Penggunaan bahan kimia untuk mengatasi masalah ini akan membawa dampak buruk bagi 6 kesehatan, sedangkan penggunaan control agent biologi yang merupakan antagonis potensial 7 bagi hama tersebut membutuhkan biaya yang besar lagi sulit untuk diterapkan. Salah satu cara 8 yang relatif murah dan mudah untuk mengatasi serangan hama larva serangga adalah dengan cara pencelupan buah ke dalam fluida (air) bersuhu cukup tinggi sehingga dapat disinfestasi

10 hama tersebut. Permasalahan yang timbul adalah buah tidak boleh terlalu lama dicelup karena 11 dikhawatirkan akan mengalami kerusakan fisik sehingga mengurangi kualitas buah tersebut.

12 Petani dapat memperoleh waktu celup yang efektif untuk proses ini dengan cara mencoba 13 beberapa kali pencelupan dan menerka berapa lama buah harus sudah diangkat agar hama bias

14 diberantas tanpa merusak buah. Namun alangkah baiknya bila ada suatu cara cepat untuk 15 mengetahui waktu celup efektif tanpa harus melakukan percobaan fisik, dengan catatan 16 diketahui sifat fisik dan sifat termal buah. Tulisan ini juga memformulasikan suatu model 17 matematika untuk tujuan memprediksi waktu celup yang efektif guna mendapatkan hasil 18 terbaik pada proses pemberantasan hama dengan cara pencelupan buah ke medium bersuhu 19 tinggi.

21 Akan dijelaskan model yang akan digunakan untuk model persamaan dalam buah ini. Proses 22 konduksi panas pada suatu medium secara fisik dipengaruhi oleh koefisien difusivitas panas, 23 yaitu besaran yang menyatakan kemampuan medium untuk menghantarkan panas. Dengan 24 mengasumsikan bahwa medium berbentuk batang, dapat dibuat suatu formulasi dalam bentuk 25 persamaan diferensial yang secara matematis dapat menjelaskan proses konduksi panas. 26 Menurut asumsi di atas hanya ada dua variabel bebas, yaitu $t$ dan $\boldsymbol{x}=(x, y, z)$, yang masing 27 masing menyatakan besaran waktu dan jarak (posisi di ruang) setiap titik pada medium 28 berbentuk batang. Jika $\theta(t, x)$ adalah fungsi yang menyatakan besarnya temperatur medium 29 pada waktu $t$ dan pada posisi $\boldsymbol{x}$, maka konduksi panas dapat dinyatakan dalam bentuk 
1 Keadaan panas yang tersebar pada awal pengamatan, yaitu pada saat $t=0$, dinyatakan dalam

2 bentuk persamaan nilai awal

$$
\theta(0, x)=\theta_{0}(x)
$$

4 Jika diasumsikan bahwa buah yang akan dicelupkan berbentuk bola berjari-jari $R$ dan 5 difusivitas panas $\alpha$ konstan, maka persamaan (11) akan menjadi

$$
\frac{\partial \theta}{\partial t}=\alpha \frac{1}{r^{2}} \frac{\partial}{\partial r} r^{2} \frac{\partial \theta}{\partial r}
$$

9 Untuk menyatakan bahwa tidak ada laju perubahan suhu di pusat bola, yaitu pada $r=0$, dan

10 bahwa suhu di permukaan buah pada saat dicelupkan adalah $T$, diperlukan dua syarat batas

11 berikut

$$
\begin{gathered}
\left.\frac{\partial \theta}{\partial r}\right|_{r=0}=0 \\
\theta(t, R)=T .
\end{gathered}
$$

14 Meskipun persamaan diferensial (13) memiliki solusi analitik, akan tetapi bentuknya tidak 15 dapat dijabarkan dalam bentuk fungsi elementer. Maka diperlukan solusi numerik. Karena 16 persamaan (13) merupakan persamaan diferensial parsial, diperlukan diskretisasi sehingga 17 dihasilkan persamaan diferensial biasa yang dapat diselesaikan menggunakan metode numerik. 18 Dalam tulisan ini digunakan metode Rothe, atau dikenal dengan nama metode garis lateral 19 [2,Ascher dkk, 1988], yaitu diskretisasi terhadap waktu $t$ terlebih dahulu dilakukan sehingga 20 untuk setiap langkah waktu diperoleh masalah syarat batas persamaan diferensial biasa berikut

$21 \quad \frac{1}{\alpha} \frac{\theta^{k+1}(r)-\theta^{k}(r)}{\Delta t}=\frac{2}{r} \frac{d \theta^{k+1}(r)}{d r}+\frac{d^{2} \theta^{k+1}(r)}{d r^{2}}$

$$
\begin{gathered}
\frac{d \theta}{d r}(0)=0, \\
\theta^{k+1}(R)=T .
\end{gathered}
$$

24 Dengan demikian solusinya dapat dicari menggunakan metode numerik yang dapat 25 menyelesaikan masalah syarat batas persamaan diferensial biasa secara numerik. Di SCILAB, 26 sebuah perangkat lunak yang bebas, memiliki rutin untuk menyelesaikan masalah syarat batas 27 sehingga metode Rothe dengan mudah dapat diimplementasikan.

\section{Hasil dan Pembahasan}


1 Dari tiap ilustrasi yang telah dikemukakan pada bagian sebelumnya, akan dibahas tentang

2 hasil apa yang diperoleh dengan menyelesaikan permasalahan di atas dengan menggunakan

3 SCILAB.

4

$5 \quad$ Persamaan Panas Sebuah Batang

6

7 Jika $\underline{z}$ menyatakan satu vektor baris berdimensi 2 yang memuat $u$ dan $u$,

$$
\underline{z}=\left(\begin{array}{l}
\underline{z_{1}} \\
\underline{z_{2}}
\end{array}\right)=\left(\begin{array}{c}
\underline{u} \\
\underline{u^{\prime}}
\end{array}\right)
$$

9 maka persamaan differensial pada persamaan (5) dapat didefinisikan sebagai berikut ini.

10 Nomor-nomor di sebelah kiri sintaks adalah penomoran baris, bukan bagian dari sintaks.

16 Langkah selanjutnya adalah menyusun syarat batas. Syarat batas pada persamaan (5) dapat

17 dituliskan sebagai

01: function $\mathrm{f}=\mathrm{fsub}(\mathrm{x}, \mathrm{z})$

02: $\mathrm{f}=(1 / \mathrm{C}) *(1 / \mathrm{tau}) *(\mathrm{z}(1)-\mathrm{u} 0(\mathrm{x}))$;

03: endfunction

$$
\begin{aligned}
& u^{k+1}(x)-u_{a}=0 \text { pada } x=0, \text { dan } \\
& u^{k+1}(x)-u_{b}=0 \text { pada } x=L .
\end{aligned}
$$

19 Sehingga sintaks untuk syarat batas persaman (5) adalah

01: zeta $=[0, \mathrm{~L}]$;

02: function $\mathrm{g}=\mathrm{gsub}(\mathrm{x}, \mathrm{z})$

03: $\mathrm{f}=[\mathrm{z}(1)-\mathrm{ua}, \mathrm{z}(1)-\mathrm{ub}] ; \mathrm{g}=\mathrm{g}(\mathrm{i})$;

04: endfunction

$27 \quad(0 \leq$ zeta $(1) \leq$ zeta $(2) \leq L)$.

28 Selain dua fungsi di atas (fsub dan gsub), diperlukan pula dua fungsi yang merepresentasikan

29 matriks Jacobi dari kedua fungsi tersebut (dfsub dan dgsub). Kedua fungsi ini didapat dengan

30 cara menurunkan masing-masing fsub dan gsub terhadap $u$ dan $u$ '. 


$$
\begin{aligned}
& \mathrm{dfsub}=\mathrm{Jac}(\mathrm{fsub})=\left(\begin{array}{ll}
\frac{\partial \mathrm{fsub}}{\partial u} & \frac{\partial \mathrm{fsub}}{\partial u^{\prime}}
\end{array}\right) \\
& =\left(\begin{array}{ll}
\frac{\partial \mathrm{fsub}}{\partial z(1)} & \frac{\partial \mathrm{fsub}}{\partial z(2)}
\end{array}\right) \\
& \operatorname{dgsub}=\operatorname{Jac}(\text { gsub })=\left(\begin{array}{cc}
\frac{\partial \operatorname{sub}_{1}}{\partial u} & \frac{\partial g \text { sub }_{1}}{\partial u^{\prime}} \\
\frac{\partial g^{\prime} \mathrm{sub}_{2}}{\partial u} & \frac{\partial g \mathrm{sub}_{2}}{\partial u^{\prime}}
\end{array}\right) \\
& =\left(\begin{array}{ll}
\frac{\partial g \operatorname{sub}(1)}{\partial z(1)} & \frac{\partial g \operatorname{sub}(1)}{\partial z(2)} \\
\frac{\partial g \operatorname{sub}(2)}{\partial z(1)} & \frac{\partial g \operatorname{sub}(2)}{\partial z(2)}
\end{array}\right)
\end{aligned}
$$

2 Maka script rangkaian perintah untuk matriks-matriks di atas adalah

3

4 01: function $\mathrm{df}=\mathrm{dfsub}(\mathrm{x}, \mathrm{z})$

$5 \quad 02: \mathrm{df}=\left[1 / \mathrm{C}^{*} \mathrm{tau}, 0\right]$;

6 03: endfunction

7 04: function $\mathrm{dg}=\mathrm{dgsub}(\mathrm{x}, \mathrm{z})$

8 05: $\mathrm{dg}=[1,0 ; 1,0] ; \mathrm{dg}=\mathrm{dg}(\mathrm{i}, \mathrm{:})$

9 06: endfunction

11 Diberikan sebuah contoh kasus persamaan panas sederhana seperti berikut. Diketahui sebuah

12 batang konduktor dengan panjang $L=1$ dengan diffusivitas termal konduktor tersebut $C=8.5$.

13 Pada saat $t=0$ dimisalkan distribusi panas pada batang konduktor tersebut diberikan

14 oleh $Q_{0}=5 \sin (x)$. Panas di ujung kiri dan kanan selalu bernilai 0. Akan digambarkan

15 perubahan distribusi panas pada batang konduktor tersebut hingga $t=7$.

16

17 Model permasalahan ini dapat dituliskan sebagai persamaan seperti berikut ini

18

$$
u_{t}=8.5 u_{x x}
$$

$$
0 \leq x \leq 1,0 \leq t \leq 10
$$

$$
u(0, x)=5 \sin (x), u(t, 0)=0, u(t, 1)=0 .
$$

19

20 dan dengan mengambil $\Delta x=0.1$ dan $\tau=\Delta t=1$, berikut adalah gambar grafik dua dimensi

21 perubahan distribusi panas untuk masalah di atas. 

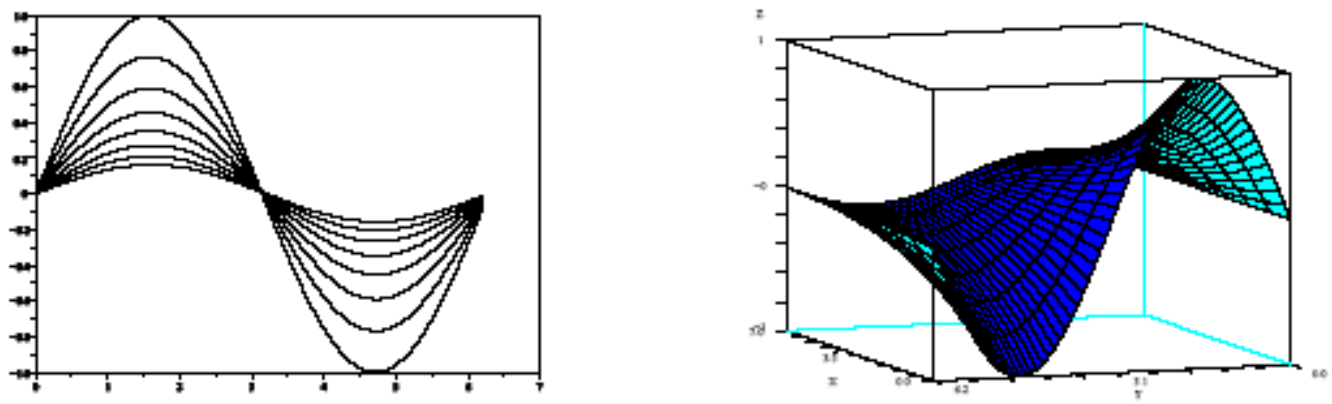

FIGURE 1. Evolusi distribusi batang untuk sejumlah waktu diskret divisualisasi dalam satu bidang gambar.

Figure 2. Evolusi distribusi panas di batang. Arah waktu menembus bidang kertas.

Gambar 1. Evolusi distribusi batang untuk sejumlah waktu diskret divisualisasi dalam satu bidang gambar.

\section{Model perlakuan panas buah untuk disinfestasi serangga}

Model simulasi dalam tulisan ini diterapkan pada buah apel malang (Malus Sylvestris Mill) dengan dua perlakuan, masing-masing perlakuan menggunakan suhu medium celup yang berbeda.

Apel Malang. Buah yang digunakan dalam percobaan ini adalah buah apel malang yang diasumsikan berbentuk bola. Asumsi untuk suhu awal apel adalah homogen sebesar $29^{\circ} \mathrm{C}$. Dalam tulisan ini dilakukan dua kali simulasi, masing-masing dengan suhu medium (air) sebesar $47^{\circ} \mathrm{C}$ dan $60^{\circ} \mathrm{C}$ dengan catatan bahwa suhu medium adalah homogen dan dijaga tetap sepanjang waktu. Dengan kadar air apel $83.33 \%$, didapat besaran-besaran konduktivitas panas sebesar $0.005979 \mathrm{Watt} / \mathrm{cm}^{0} \mathrm{C}$ dan difusivitas panas $2.0990 \times 10^{-3} \mathrm{~cm}^{2} / \mathrm{dtk}$. [5, Fahmi, 2004].

Lalat Buah (Rhagoletis Pomonella). Menurut Fields (2002)[6], suhu mematikan bagi serangga terletak pada rentang yang dapat dilihat pada tabel berikut. 


\begin{tabular}{|c|c|}
\hline $\begin{array}{c}\text { Rentang temperatur mematikan } \\
\left({ }^{0}\right) \mathrm{C}\end{array}$ & Efek \\
\hline Di atas 62 & Mati kurang dari 1 menit \\
\hline 50 hingga 62 & Mati kurang dari 1 jam \\
\hline 45 hingga 50 & Mati kurang dari 1 hari \\
\hline 35 hingga 42 & $\begin{array}{c}\text { Serangga mulai mencari } \\
\text { tempat yang lebih dingin }\end{array}$ \\
\hline
\end{tabular}

Tulisan ini mengasumsikan larva lalat buah hidup pada daerah yang tidak lebih dalam daripada $0.5 \mathrm{~cm}$ dari kulit buah. Dari data-data tersebut dapat dilakukan simulasi pencelupan buah dengan menggunakan metode numerik. Dengan menggunakan software SCILAB, solusi numerik persamaan panas di atas dapat digunakan untuk memprediksi waktu celup efektif.

Berikut ini disajikan hasil simulasi dua kasus untuk suhu medium yang berbeda.

Kasus Pertama. Dengan mengambil suhu medium luar sebesar $47^{\circ} \mathrm{C}$ didapatkan hasil dalam bentuk kurva sebaran panas seperti berikut. Simulasi dilakukan dengan mengambil langkah waktu 5 menit, selama 80 menit. Suhu awal buah dianggap sama dengan suhu ruang yaitu $29^{\circ} \mathrm{C}$.

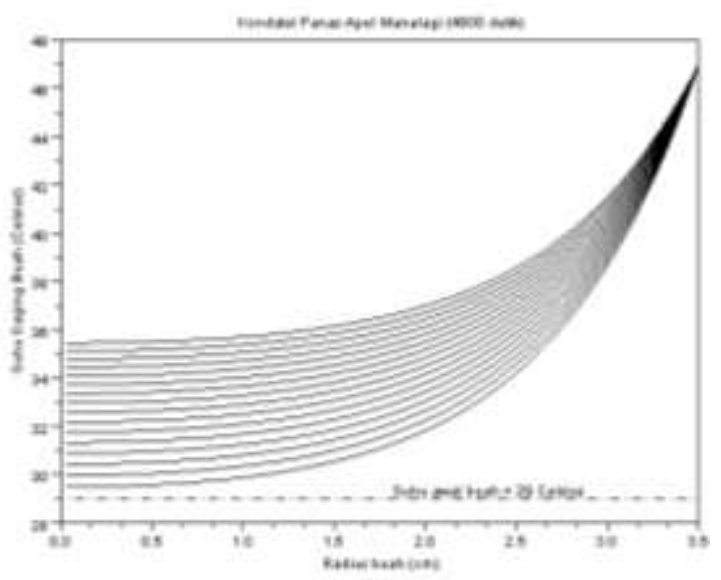

Gambar 4. Hasil simulasi dengan suhu medium $47^{\circ} \mathrm{C}$

Kasus Kedua. Dengan mengambil suhu medium sebesar $60^{\circ} \mathrm{C}$ didapatkan hasil dalam bentuk kurva sebaran panas seperti berikut. Seperti halnya kasus pertama, langkah waktu, jangka waktu dan suhu awal buah kita ambil sama. 


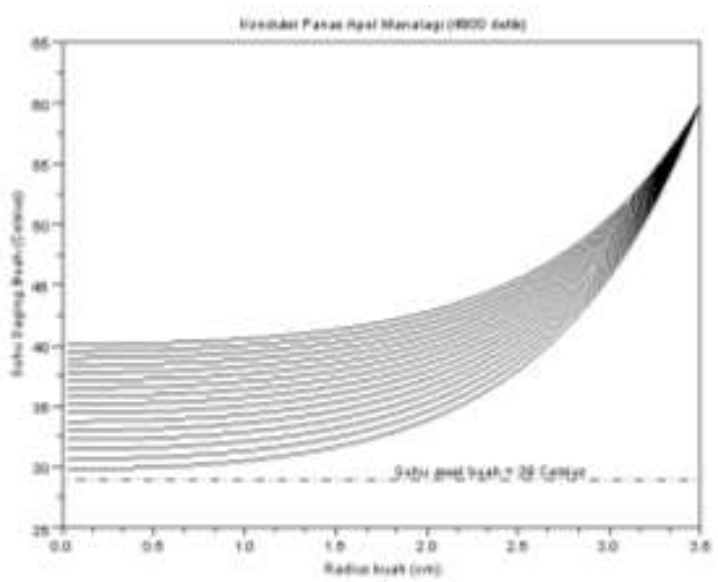

Gambar 5. Hasil simulasi dengan suhu medium $60^{\circ} \mathrm{C}$

Untuk kasus pertama, di akhir simulasi diketahui bahwa suhu pada kedalaman $0.5 \mathrm{~cm}$ dari kulit buah mencapai sekitar $41.5^{\circ} \mathrm{C}$. Artinya, menurut tabel 1, bahwa proses pencelupan untuk kasus pertama ini gagal mengusir serangga yang ada pada kedalaman tersebut. Serangga yang terusir akibat proses pencelupan ini hanyalah serangga yang ada hingga kedalaman $0.7 \mathrm{~cm}$ dari kulit buah. Karena dikhawatirkan bahwa jika waktu pencelupan buah diperpanjang maka akan mengakibatkan kerusakan fisik buah, maka yang perlu dilakukan adalah menaikkan suhu medium tempat buah dicelup. Pada kasus kedua diperoleh bahwa setelah buah dicelupkan

11 selama 80 menit, suhu pada kedalaman $0.5 \mathrm{~cm}$ dari kulit mencapai $51^{\circ} \mathrm{C}$. Kembali mengacu

12 pada tabel 1, dapat diketahui bahwa serangga yang hidup hingga kedalaman tersebut dapat 13 terusir oleh penetrasi panas yang terjadi akibat proses pencelupan. Kesimpulan Proses 14 pencelupan buah ke dalam medium bersuhu tinggi dapat dilakukan guna mengusir serangga 15 yang berpotensial hidup dalam daging buah. Namun perlu diperhatikan bahwa penetrasi panas 16 yang terjadi akibat proses ini dapat menyebabkan kerusakan fisik buah yang pada akhirnya 17 akan menurunkan kualitas buah. Untuk itu suhu medium dan waktu celup harus diambil sedemikian sehingga serangga yang hidup dalam daging buah dapat diusir tanpa merusak buah.

19 Simulasi menggunakan model persamaan panas dapat digunakan untuk mengetahui kombinasi 20 yang tepat antara suhu medium dan waktu celup sehingga proses pencelupan memberikan 21 hasil yang optimal.

\section{Kesimpulan}


1 Telah didemonstrasikan implementasi penyelesaian numerik persamaan differensial parsial 2 evolusi dengan satu dimensi spasial dalam SCILAB dengan memanfaatkan rutin untuk 3 menyelesaikan masalah syarat batas yang disediakannya.

5 Terbuka kesempatan pengembangan teknik metode garis lateral sebagai pustaka numerik di

6 lingkungan SCILAB, menjadi pustaka yang setara dengan pdepe dengan mengikuti rancangan 7 yang digariskan oleh Schryer [11] . Dengan kerangka yang diberikan Schryer tersebut, 8 dimungkinkan memanfaatkan metode ini untuk menyelesaikan berbagai aplikasi dari 9 persamaan panas dan model perlakuan panas buah untuk disinfestasi serangga.

11 The root mean square error between simulated and measured temperatures was all below $8 \%$.

12 The comparison analysis showed that the simulation results were in good agreement with the 13 measured values, which indicates the reliability of the simulation model. With the validated 14 simulation model, the impacts of various parameters on heating rates were systematically 15 studied using forced hot air. To reach the same thermal effect, hot water $\left(55^{\circ} \mathrm{C}\right)$ heating time 16 was about $30 \%$ in hot air $\left(55^{\circ} \mathrm{C}\right)$ treatments. Water was more efficient medium than air. 17 Increasing air speed increased heating rates, but water circulation speeds had little impact on 18 heat transfer rate. The most important parameters in the model included the fruit size, fruit 19 shape and the heating medium followed by the heating medium speed and thermal diffusivity. 20 This study demonstrated that the computer simulation model can be used to evaluate the 21 impacts of various heating parameters on the temperature-time history in fruits. These 22 parameters include fruit size, fruit shape, heating medium speed, and thermal diffusivity. 23 Combining the hot air or hot water treatment with the fast heating method, e.g. radio 24 frequency or microwave energy, further improves the fruit heating efficiency since 25 electromagnetic energy may eliminate conduction as a major rate-limiting factor directly 26 delivered to the fruit interior. Furthermore, when combined with insect mortality and quality 27 kinetic information, the model can be used to support for the heat treatment process and 28 optimize the process parameters in postharvest thermal disinfestations. 
Terima kasih kepada: Dwi C. Ekastrya, Verawati, dan Prasetyaning D. R. Lestari atas bantuannya.

\section{Daftar Pustaka}

[1] Ascher, U., J. Christiansen, dan R.D. Russel. 1981. Collocation Software for Boundary Value ODEs, ACM Transactions on Mathematical Software, Vol.7, No.2.

[2] Ascher, U., R. M. Mattheij, dan R.D Russel. 1988. Numerical Solution of Boundary Value Problem, New Jersey: Prentice-Hall.

[3] Campbell, S.L., J.P. Chancelier, and R.. Nikoukhah. 2005. Modeling and Simulation in SCILAB/Scicos, Springer.

[4] Garnadi, A. D., F. Ayatullah, D.C. Ekastrya, M.T. Julianto, S. Nurdiati, W. Erliana, 2015, Menyelesaikan Persamaan Differensial Biasa dalam SCILAB menggunakan bvode. JMA v14n1, 55-68.

[5] Fahmi, A. 2004. Kajian Penetrasi panas pada buah apel (Malus Sylvestris Mill) selama proses heat treatment. Tesis (Pascasarjana)-Institut Pertanian Bogor.

[6] Fields, P.G. 2002. Alternatives to Methyl Bromide Treatments for Stored-Product and Quarantine Insects. Annu. Rev. Entomol, 47:X.X. Cereal Research Centre, Agriculture and Agri-Food Canada.

[7] Garnadi, A.D. 2004. Masalah Syarat Batas Bebas Persamaan Diferensial Parsial Parabolik Satu Dimensi. JMA, v3n2, pp-pp. ?????

[8] Madsen, N.K. dan R.F. Sincovec. 1979. ALGORITHM 540: PDECOL, General Collocation Software for Partial Differential Equations, ACM Transactions on Mathematical Software, Vol. 5, No.3, 326-327.

[9] May, R.L. 1990. Numerical Solution of PDE's using The Methods of Lines, TR No. 2, Dept. Math., RMIT.

[10] Poulikakos, D. 1994. Conduction Heat Transfer, New Jersey: Prentice-Hall International.

[11] Schryer, N.L. 1990. Designing Software for One-Dimensional Partial Differential Equations, ACM Transactions on Mathematical Software. Vol. 16, No.1,72-85.

[12] Skeel, R.D. dan M. Berzins. 1990. A Method for the Spatial Discretization of Parabolic Equations in One Space Variable, SIAM J. Sci.Stat.Comp., v11, 1-32.

[13] Wirakartakusumah, M.A., K. Abdullah dan A. M. Syarif. 1992. Sifat Fisik Pangan. Departemen Pendidikan dan Kebudayaan, Direktorat Jenderal Pendidikan Tinggi, Pusat Antar Universitas Pangan dan Gizi, Bogor: Institut Pertanian Bogor.

[14] Fallik, E. dan Z. Ilic, 2017. Hot Water Treatments. In Novel Postharvest Treatments of Fresh Produce (pp. 269-286). CRC Press.

[15] Paulus, E., M. Suryani, I. Suryana, D. Chaerani, 2018, Perangkat Komputasi Numerik SCILAB, deepublish. 


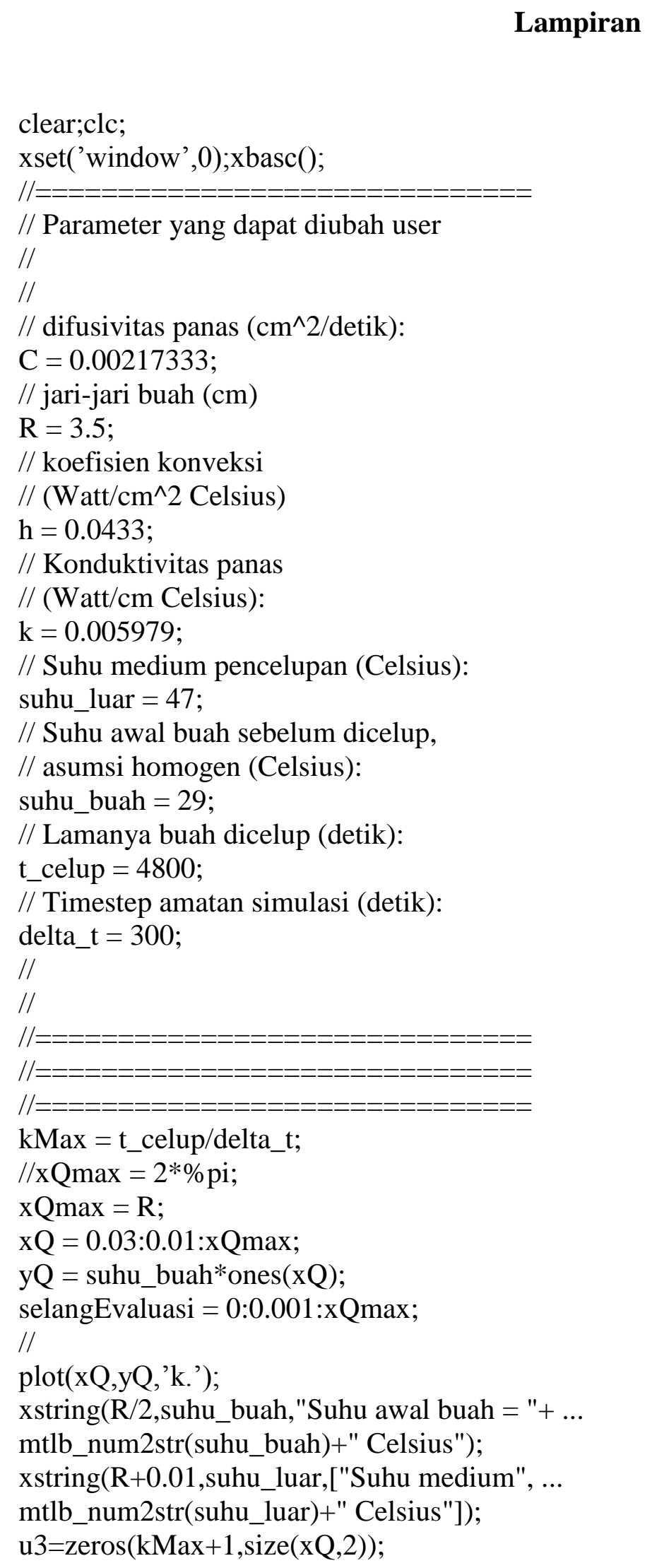




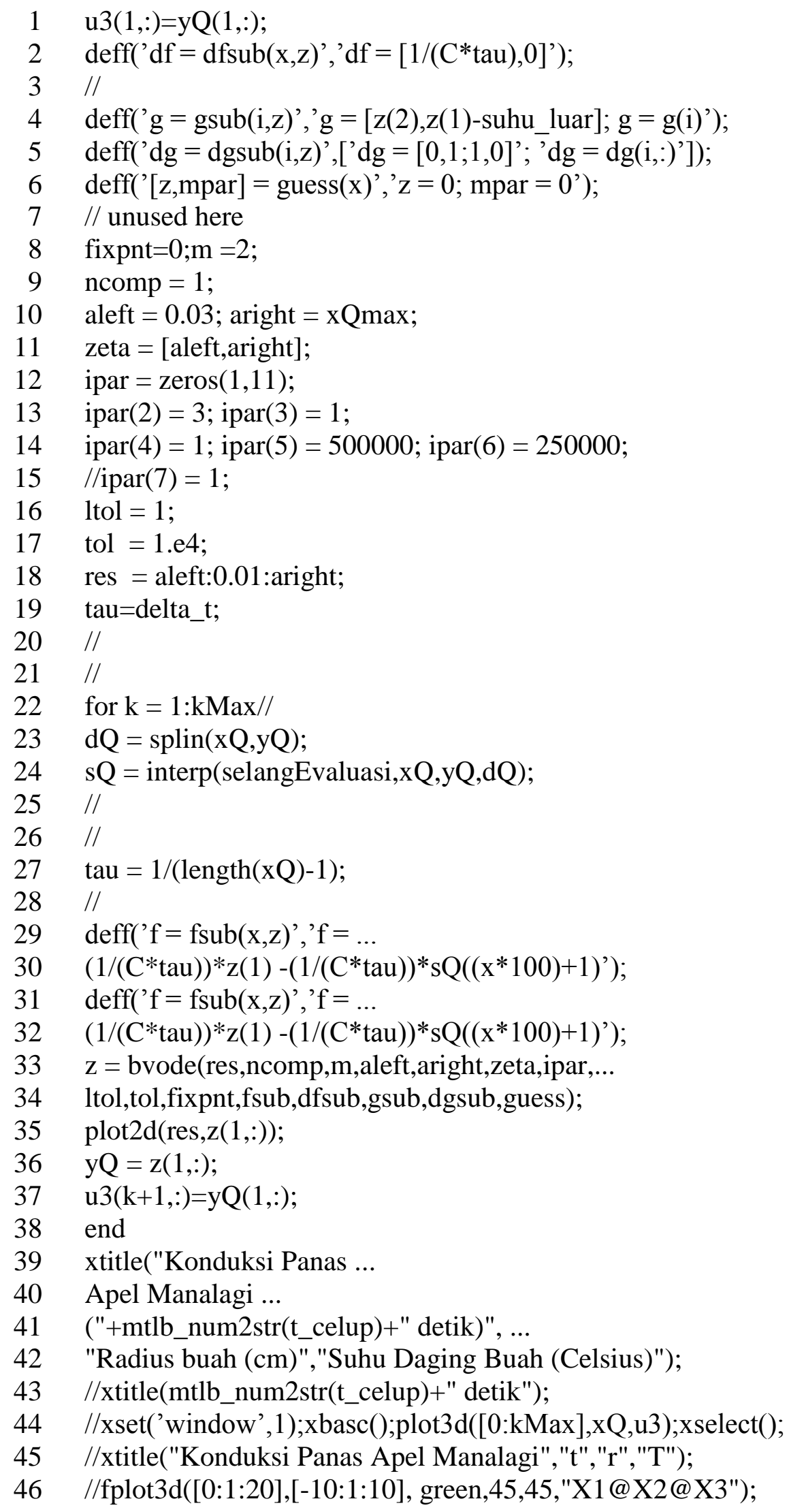


1 printf("\ndoneln")

2 // 


\section{BAB 3. METODE GARIS LATERAL UNTUK OPSI EROPA}

Persamaan diferensial parsial parabolik, merupakan salah satu dari sekian banyak persamaan differensial yang sangat berperan dalam memodelkan berbagai masalah yang timbul dari ragam fenomena di sekitar kita. Meskipun beberapa persamaan panas yang tergolong sederhana dapat dicari solusi eksaknya, namun banyak permasalahan yang dimodelkan dalam persamaan panas dimana solusi eksak sulit dicari atau bahkan sama sekali tidak memiliki solusi eksak. Alternatifnya, bila solusinya ada dan tidak dapat diperoleh secara eksak, adalah dengan menyelesaikan persamaan panas tersebut secara numerik. Untuk itu dibutuhkan rutin (program) yang mampu menyelesaikan Persamaan Differensial Parsial (PDP) secara numerik. Namun hingga saat ini sedikit sekali perangkat lunak numerik yang menyediakan rutin untuk keperluan ini. Di lain pihak, rutin-rutin yang mampu menyelesaikan Persamaan Differensial Biasa (PDB) telah banyak berkembang dan sudah menjadi paket yang sudah jadi di hampir setiap perangkat lunak numerik yang ada saat ini.

Tujuan tulisan ini menyajikan tutorial yang menunjukkan teknik penyelesaian persamaan panas secara numerik dengan memanfaatkan rutin numerik untuk menyelesaikan Masalah Syarat Batas (MSB) untuk PDB. Rutin yang digunakan adalah rutin yang tersedia di dalam Scilab yang bernama bvode. Untuk tutorial penggunaan serta keterangan mengenai bvode dapat dilihat pada [4]. Salah satu metode untuk menyelesaikan secara numerik persamaan evolusi, dikenal dengan metode garis $([8,9])$. Metode ini dilakukan dengan cara melakukan diskretisasi ruang dengan mempergunakan beda hingga ([9]) atau kolokasi ([8, 12]) misalnya, sehingga diperoleh sebuah masalah nilai awal untuk sebuah sistem PDB. Kemudian, dapat digunakan berbagai rutin numerik yang tersedia untuk menyelesaikan sistem PDB tersebut. Di dalam PSE komersial MATLAB disediakan pdepe untuk menyelesaikan persamaan parabolik 1-dimensi spasial, rutin ini didasarkan pada ([12]) yang mempergunakan metode kolokasi untuk diskretisasi ruang. Pendekatan lain untuk menyelesaikan persamaan diferensial parsial evolusi ialah menggunakan strategi diskretisasi waktu terlebih dulu, sehingga diperoleh MSB PDB untuk setiap langkah waktu. Dengan demikian, secara bertingkat diselesaikan secara berturutan harus diselesaikan MSB PDB. Teknik seperti ini sering sekali dikenal sebagai metode garis lateral, atau dikenal juga dengan metode Rothe. Dalam [7], terdapat ulasan singkat mengenai metode garis lateral ini. Salah satu tujuan tulisan ini ialah sebagai tutorial penggunaan perangkat lunak numerik untuk menyelesaikan persamaan diferensial parabolik secara umum. Tujuan lain dari tulisan ini ialah mendukung Indonesian Goes Open Source (IGOS) di bidang Scientific Computing, mengingat Scilab merupakan perangkat lunak yang bebas. Selain itu, tulisan ini sebagai langkah awal penyediaan perangkat alternatif dari perangkat lunak komersial MATLAB yang cukup populer, dimana tersedia pdepe. Tulisan ini disusun seperti berikut ini, pertama akan diingatkan terkait dengan persamaan panas. Kemudian secara singkat akan diperlihatkan diskretisasi waktu, sehingga diperoleh bentuk masalah syarat batas PDB untuk setiap langkah waktu diskret. Dengan demikian, bentuk ini dapat dikonversikan sehingga dapat diselesaikan dengan mempergunakan bvode dalam SCILAB. Dilanjutkan dengan bagian berikutnya yang memperlihatkan susunan lengkap implementasi metode garis lateral untuk menyelesaikan persamaan panas dan aplikasinya dalam SCILAB. 


\section{BAHAN DAN METODE}

Pada makalah ini akan dibahas model Opsi Jual Eropa, dengan menggunakan metode garis lateral.

\section{Persamaan Panas}

Jika pada waktu $t=0$ sebuah batang konduktor termal, selanjutnya kita katakan konduktor, dengan panjang L memiliki suhu yang terdistribusi menurut rumus $Q_{0}=u_{0}(x)$, maka setelah beberapa saat suhu di batang tersebut akan terdistribusi pada batang konduktor menurut persamaan

$$
\begin{gathered}
\frac{\partial u(t, x)}{\partial t}=C \frac{\partial^{2} u(t, x)}{\partial x^{2}}, \\
0 \leq x \leq L, t \geq 0
\end{gathered}
$$

Sebagai tambahan, untuk $t \geq 0$, jika batang konduktor tersebut dipanasi atau didinginkan akibat adanya sumber panas $Q_{\text {eksternal }}=f(t, x)$, maka persamaan (1) akan menjadi

$$
\begin{aligned}
& \frac{\partial u(t, x)}{\partial t}=C \frac{\partial^{2} u(t, x)}{\partial x^{2}}+f(t, x), \\
& 0 \leq x \leq L, t \geq 0
\end{aligned}
$$

Persamaan (1) dan (2) dikenal dengan nama persamaan panas dimana $C$ adalah diffusivitas termal benda yang dipanasi. Bersama dengan nilai-nilai awal yang diketahui, persamaan (1) dan (2) merupakan masalah syarat batas

$$
\begin{aligned}
& \frac{\partial u(t, x)}{\partial t}=C \frac{\partial^{2} u(t, x)}{\partial x^{2}}+f(t, x), \\
& 0 \leq x \leq L, t \geq 0 ; \\
& u(x, 0)=u_{0}(x), u(t, 0)=u_{a}, u(t, L)=u_{b} .
\end{aligned}
$$

dengan $u_{a}$ dan $u_{b}$ masing-masing menyatakan suhu pada ujung-ujung batang konduktor tersebut.

Dengan metode diskretisasi waktu, selang $t$ yang kontinu digantikan oleh titik-titik diskrit yang membentuk mesh. Turunan waktu yang ada pada persamaan (3) dihampiri dengan beda hingga (finite difference), sehingga persamaan (3) menjadi

$$
\begin{aligned}
& \frac{u^{k+1}(x)-u^{k}(x)}{\Delta t}=C \frac{d^{2} u^{k+1}(x)}{d x^{2}}+f^{k+1}(x), \\
& 0 \leq x \leq L, k=0,1,2, \ldots . ; \\
& u^{0}(x)=u_{0}(x), u^{k+1}(0)=u_{a}, u^{k+1}(L)=u_{b} .
\end{aligned}
$$

Perhatikan bahwa persamaan (4) merupakan masalah syarat batas dari persamaan differensial biasa orde 2 yang dapat dicari solusi numeriknya menggunakan bvode untuk setiap langkah waktu ke $k$. Dengan menyusun kembali penulisannya, persamaan (4) akan menjadi

$$
\begin{aligned}
& \frac{d^{2} u^{k+1}(x)}{d x^{2}}=\frac{1}{C} \frac{u^{k+1}(x)-u^{k}(x)}{\Delta t}-f^{k+1}(x), \\
& 0 \leq x \leq L, k=0,1,2, \ldots . ; \\
& u^{0}(x)=u_{0}(x), u^{k+1}(0)=u_{a}, u^{k+1}(L)=u_{b} .
\end{aligned}
$$

Persamaan differensial biasa (5) berorde 2. Dengan demikian, akibat diskretisasi pada langkah waktu, memungkinkan penggunaan bvode untuk mencari solusi numerik MSB, sehingga untuk setiap langkah waktu diperoleh profil distribusi panas. 


\section{Model Opsi Jual Eropa}

Persamaan Black-Scholes biasa digunakan untuk mencari nilai opsi Eropa. Persamaan ini merupakan persamaan diferensial parsial berupa persamaan panas (parabolik) dengan syarat batas Dirichlet. Akan tetapi, yang diperhatikan di sini bukan waktu awalnya, melainkan waktu akhir. Ada banyak program yang dapat digunakan untuk menyelesaikan persamaan panas tetapi tulisan ini hanya akan membahas cara menyelesaikan persamaan panas dalam Scilab, khususnya untuk persamaan Black-Scholes, dengan bvode.

Untuk persamaan panas Black-Scholes didefinisikan waktu akhir suatu opsi $\tau=(T-t)$. Persamaan panas Black-Scholes berupa:

$$
\begin{aligned}
& \frac{\partial C}{\partial \tau}-\frac{1}{2} \sigma^{2} S^{2} \frac{\partial^{2} C}{\partial S^{2}}-r S \frac{\partial C}{\partial S}+r C=0 \\
& 0 \leq S \leq L, 0 \leq \tau \leq T
\end{aligned}
$$

dengan nilai awal:

$$
C(0, S)=\max (S(0)-E, 0)
$$

dan syarat batas:

$$
C(\tau, 0)=0, \quad C(\tau, S) \approx S-E e^{-r \tau}
$$

untuk $S$ yang besar.

Perhatikan bahwa persamaan (6) di atas memiliki bentuk yang mirip dengan persamaan panas

$$
\begin{aligned}
& \frac{\partial u(t, x)}{\partial t}=C \frac{\partial^{2} u(t, x)}{\partial x^{2}}+f(t, x) \\
& 0 \leq x \leq L, t \geq 0
\end{aligned}
$$

Dengan menuliskan

$$
\begin{aligned}
& a(S)=\frac{1}{2} \sigma^{2} S^{2} \\
& b(S)=r S \\
& c(S)=-r
\end{aligned}
$$

maka persamaan (6) dapat dituliskan lengkap bersama dengan nilai awal dan syarat batasnya dalam bentuk berikut:

$$
\begin{aligned}
& \frac{\partial C(\tau, S)}{\partial \tau}=a(S) \frac{\partial^{2} C(\tau, S)}{\partial S^{2}}+b(S) \frac{\partial C(\tau, S)}{\partial S}+c(S) C(\tau, S) \\
& 0 \leq S \leq L, 0 \leq \tau \leq T \\
& C(0, S)=\max (S(0)-E, 0), C(\tau, 0)=0, C(\tau, S) \approx S-E e^{-r \tau}
\end{aligned}
$$

Rutin bvode tidak dapat mencari solusi numerik persamaan (8) karena bentuknya yang parsial. Namun demikian, metode diskretisasi utuh memungkinkan penggunaan bvode untuk mencari solusi numerik persamaan panas.

Dengan melakukan diskretisasi pada waktu, selang $\tau$ yang kontinu digantikan oleh titik-titik diskrit yang membentuk mesh. Turunan terhadap waktu pada persamaan (8) digantikan dengan menggunakan pendekatan beda hingga, sehingga persamaan (8) menjadi

$$
\begin{aligned}
& \frac{C^{k+1}(S)-C^{k}(S)}{\Delta \tau}=a(S) \frac{d^{2} C^{k+1}(S)}{d S^{2}}+b(S) \frac{d d^{k+1}(S)}{d S}+c(S) C^{k+1}(S) \\
& S=0, \Delta S, 2 \Delta S, \ldots, \ldots, L, k=0,1,2, \ldots \\
& C^{0}(S)=\max (S(0)-E, 0), C^{k+1}(0)=0, C^{k+1}(S) \approx S-E e^{-\pi \tau}
\end{aligned}
$$

Persamaan (9) dapat dicari solusi numeriknya menggunakan bvode secara iteratif dengan menganggap $k$ sebagai indeks iterasinya. Dengan memisahkan variabel-takbebasnya, persamaan (9) akan menjadi 


$$
\begin{aligned}
& \frac{d^{2} C^{k+1}(S)}{d S^{2}}=\frac{1}{a(S)}\left(\frac{C^{k+1}(S)-C^{k}(S)}{\Delta \tau}-b(S) \frac{d C^{k+1}(S)}{d S}-c(S) C^{k+1}(S)\right) \\
& S=0, \Delta S, 2 \Delta S, \ldots \ldots, L, k=0,1,2, \ldots \\
& C^{0}(S)=\max (S(0)-E, 0), C^{k+1}(0)=0, C^{k+1}(S) \approx S-E e^{-r \tau}
\end{aligned}
$$

\section{HASIL DAN DISKUSI}

Dari tiap ilustrasi yang telah dikemukakan pada bagian sebelumnya, akan dibahas tentang hasil apa yang diperoleh dengan menyelesaikan permasalahan di atas dengan menggunakan Scilab.

\section{Persamaan Panas}

Jika $\underline{z}$ menyatakan satu vektor baris berdimensi 2 yang memuat $u$ dan $u$ '

$$
\underline{z}=\left(\begin{array}{l}
\underline{z_{1}} \\
\underline{z_{2}}
\end{array}\right)=\left(\begin{array}{c}
\underline{u} \\
\underline{u}
\end{array}\right)
$$

maka persamaan differensial pada persamaan (5) dapat didefinisikan sebagai berikut ini. Nomor-nomor di sebelah kiri sintaks adalah penomoran baris, bukan bagian dari sintaks.

01: function $\mathrm{f}=\mathrm{fsub}(\mathrm{x}, \mathrm{z})$

02: $\mathrm{f}=(1 / \mathrm{C})^{*}(1 / \mathrm{tau})^{*}(\mathrm{z}(1)-\mathrm{u} 0(\mathrm{x}))$;

03: endfunction

Langkah selanjutnya adalah menyusun syarat batas. Syarat batas pada persamaan (5) dapat dituliskan sebagai

$$
\begin{aligned}
& u^{k+1}(x)-u_{a}=0 \text { pada } x=0, \text { dan } \\
& u^{k+1}(x)-u_{b}=0 \text { pada } x=L .
\end{aligned}
$$

Sehingga sintaks untuk syarat batas persaman (5) adalah

01: zeta $=[0, \mathrm{~L}]$;

02: function $\mathrm{g}=\mathrm{gsub}(\mathrm{x}, \mathrm{z})$

03: $\mathrm{f}=[\mathrm{z}(1)-\mathrm{ua}, \mathrm{z}(1)-\mathrm{ub}] ; \mathrm{g}=\mathrm{g}(\mathrm{i})$;

04: endfunction

Yang perlu diperhatikan adalah bahwa nilai batas $x=0$ dan $x=L$ dituliskan secara berurutan $(0 \leq z e t a(1) \leq z e t a(2) \leq L)$.

Selain dua fungsi di atas (fsub dan gsub), diperlukan pula dua fungsi yang merepresentasikan matriks Jacobi dari kedua fungsi tersebut (dfsub dan dgsub). Kedua fungsi ini didapat dengan cara menurunkan masing-masing fsub dan gsub terhadap $u$ dan $u$ '. 


$$
\begin{aligned}
& \mathrm{dfsub}=\mathrm{Jac}(\mathrm{fsub})=\left(\begin{array}{ll}
\frac{\partial \mathrm{fsub}}{\partial u} & \frac{\partial \mathrm{fsub}}{\partial u^{\prime}}
\end{array}\right) \\
& =\left(\begin{array}{ll}
\frac{\partial \mathrm{fsub}}{\partial z(1)} & \frac{\partial \mathrm{fsub}}{\partial z(2)}
\end{array}\right) \\
& \operatorname{dgsub}=\mathrm{Jac}(\text { gsub })=\left(\begin{array}{cc}
\frac{\partial g \mathrm{sub}_{1}}{\partial u} & \frac{\partial g \mathrm{sub}_{1}}{\partial u^{\prime}} \\
\frac{\partial g \mathrm{gub}_{2}}{\partial u} & \frac{\partial g \mathrm{sub}_{2}}{\partial u^{\prime}}
\end{array}\right) \\
& =\left(\begin{array}{ll}
\frac{\partial g \operatorname{sub}(1)}{\partial z(1)} & \frac{\partial g \operatorname{sub}(1)}{\partial z(2)} \\
\frac{\partial g \operatorname{sub}(2)}{\partial z(1)} & \frac{\partial g \operatorname{sub}(2)}{\partial z(2)}
\end{array}\right)
\end{aligned}
$$

Maka script rangkaian perintah untuk matriks-matriks di atas adalah

01: function $\mathrm{df}=\mathrm{dfsub}(\mathrm{x}, \mathrm{z})$

02: $\mathrm{df}=\left[1 / \mathrm{C}^{*}\right.$ tau, 0$]$;

03: endfunction

04: function $\mathrm{dg}=\mathrm{dgsub}(\mathrm{x}, \mathrm{z})$

$05: \operatorname{dg}=[1,0 ; 1,0] ; \operatorname{dg}=\operatorname{dg}(\mathrm{i},:)$

06: endfunction

Diberikan sebuah contoh kasus persamaan panas sederhana seperti berikut. Diketahui sebuah batang konduktor dengan panjang $L=1$ dengan diffusivitas termal konduktor tersebut $C=8.5$. Pada saat $t=0$ dimisalkan distribusi panas pada batang konduktor tersebut diberikan oleh $Q_{0}=5 \sin (x)$. Panas di ujung kiri dan kanan selalu bernilai 0 . Akan digambarkan perubahan distribusi panas pada batang konduktor tersebut hingga $t=7$.

Model permasalahan ini dapat dituliskan sebagai persamaan seperti berikut ini

$$
\begin{aligned}
& u_{t}=8.5 u_{x x} \\
& 0 \leq x \leq 1,0 \leq t \leq 10, \\
& u(0, x)=5 \sin (x), u(t, 0)=0, u(t, 1)=0 .
\end{aligned}
$$

dan dengan mengambil $\Delta x=0.1$ dan $\tau=\Delta t=1$, berikut adalah gambar grafik dua dimensi perubahan distribusi panas untuk masalah di atas.

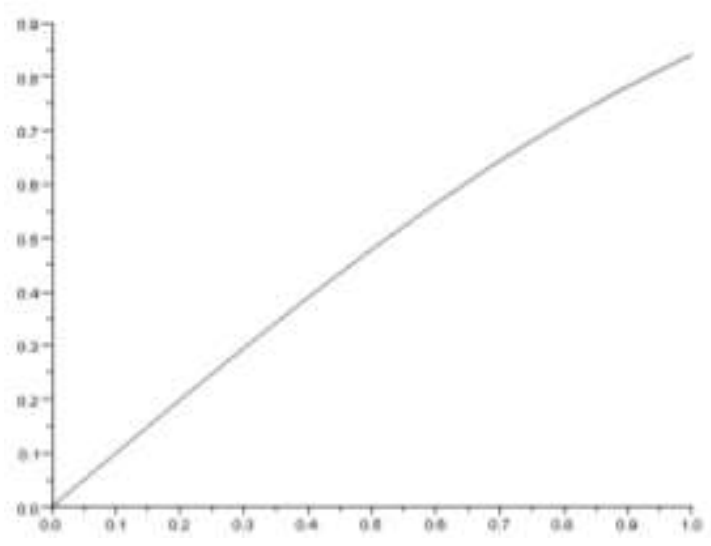

Gambar 1. Evolusi distribusi batang untuk sejumlah waktu diskret divisualisasi dalam satu bidang gambar.

\section{Model Opsi Jual Eropa}


Dari bagian sebelumnya persamaan differensial biasa (10) berorde 2. Misalkan $z$ adalah suatu vektor (kolom) berdimensi 2 yang memuat $C$ dan $C$ '

$$
\underline{z}=\left(\begin{array}{l}
\underline{z}_{1} \\
z_{2}
\end{array}\right)=\left(\begin{array}{l}
\underline{c} \\
\underline{c}^{\prime}
\end{array}\right) .
$$

Karena persamaan differensial biasa (10) yang dihasilkan dari pendiskretisasian (9) berorde 2 maka persamaan (10) dapat dinotasikan sebagai $f\left(\tau, C(\tau, S), C^{\prime}(\tau, S)\right)$. Dengan menggunakan pemisalan di atas, notasi persamaan (10) menjadi $f(\tau, \underline{z})$.. Dalam Scilab, semua variabel berstruktur data array. Karena vektor , $\underline{z}$, dapat direpresentasikan dalam bentuk array, maka kita dapat dengan mudah mendefinisikan persamaan (10) dalam bentuk fungsi Scilab seperti berikut. Nomornomor di sebelah kiri sintaks adalah penomoran baris, bukan bagian dari sintaks.

01: function $\mathrm{f}=\mathrm{fsub}(\mathrm{S}, \mathrm{z})$

02: $\mathrm{f}=(1 / \mathrm{a}(\mathrm{S}))^{*}(\ldots$

03: $\quad(1 / \mathrm{tau}) *(\mathrm{z}(1)-\mathrm{C}(\mathrm{S})) \ldots$

04: $\quad-b(S) * z(2) \ldots$

05: $\quad-c(S) * z(1) \ldots$

06: $\quad$ );

07: endfunction

Langkah selanjutnya adalah menyusun syarat batas. Syarat batas pada persamaan (10) dapat dituliskan sebagai

$$
\begin{aligned}
& C^{k+1}(S)=0 \quad \text { pada } S=0, \text { dan } \\
& C^{k+1}(S)-S+E e^{-r \tau} \quad \text { pada } S \approx L
\end{aligned}
$$

sehingga sintaks untuk syarat batas persamaan (10) adalah

01 : zeta $=[0, \mathrm{~L}]$;

02: function $\mathrm{g}=\mathrm{gsub}(\mathrm{S}, \mathrm{z})$

03: $\mathrm{g}=\left[\mathrm{z}(1), \mathrm{z}(1)-\mathrm{L}+\mathrm{E}^{*} \operatorname{Exp}\left(-\mathrm{r}^{*} \operatorname{tau}\right)\right.$;

04: $\mathrm{g}=\mathrm{g}(\mathrm{i})$;

05: endfunction

Yang perlu diperhatikan adalah bahwa nilai batas $S=0$ dan $S=L$ dituliskan secara berurutan $(0 \leq z e t a(1) \leq z \operatorname{eta}(2) \leq L)$.

Selain dua fungsi di atas (fsub dan gsub), diperlukan pula dua fungsi yang merepresentasikan matriks Jacobi dari kedua fungsi tersebut (dfsub dan dgsub). Kedua fungsi ini didapat dengan cara menurunkan masing-masing fsub dan gsub terhadap $C$ dan $C$ '.

$$
\begin{aligned}
& \text { dfsub=Jac (fsub) }=\left(\begin{array}{ll}
\frac{\partial \text { fsub }}{\partial C} & \frac{\partial \text { fsub }}{\partial C^{\prime}}
\end{array}\right)=\left(\begin{array}{ll}
\frac{\partial \text { fsub }}{\partial z(1)} & \frac{\partial \text { fsub }}{\partial z(2)}
\end{array}\right) \\
& \operatorname{dgsub}=\mathrm{Jac}(\mathrm{gsub})=\left(\begin{array}{cc}
\frac{\partial \operatorname{ssub}_{1}}{\partial C} & \frac{\partial g \operatorname{sub}_{1}}{\partial C^{\prime}} \\
\frac{\partial \operatorname{sub}_{2}}{\partial C} & \frac{\partial g \operatorname{sub}_{2}}{\partial C^{\prime}}
\end{array}\right)=\left(\begin{array}{cc}
\frac{\partial g \operatorname{sub}(1)}{\partial z(1)} & \frac{\partial g \operatorname{sub}(1)}{\partial z(2)} \\
\frac{\partial g \operatorname{sub}(2)}{\partial z(1)} & \frac{\partial g \operatorname{sub}(2)}{\partial z(2)}
\end{array}\right)
\end{aligned}
$$

Sintaks untuk matriks-matriks di atas adalah

01: function $\mathrm{df}=\mathrm{dfsub}(\mathrm{S}, \mathrm{z})$

02: $\mathrm{df}=[(1 / \mathrm{tau})-\mathrm{c}(\mathrm{S}) / \mathrm{a}(\mathrm{S}),-\mathrm{b}(\mathrm{S}) / \mathrm{a}(\mathrm{S})]$;

03: endfunction

04: function $\mathrm{dg}=\mathrm{dgsub}(\mathrm{S}, \mathrm{z})$

$05: \mathrm{dg}=[1,0 ; 1,0] ; \operatorname{dg}=\mathrm{dg}(\mathrm{i},:)$;

06: endfunction 
Berikut diberikan contoh numerik menyelesaikan persamaan Black-Scholes dengan cara menyusun beberapa fungsi dan setting variabel yang menjadi argumen bagi bvode. Diberikan $E=4, \sigma=0.5, r=0.03, T=1, N S=11, N T=29$, dan $L=10$, berarti $k=\Delta T=T / N T$ dan $h=\Delta S=L / N S$. Permasalahan ini dapat dimodelkan sebagai berikut:

$$
\begin{aligned}
& \frac{\partial C(\tau, S)}{\partial \tau}=\frac{1}{2}(0.5)^{2} S^{2} \frac{\partial^{2} C(\tau, S)}{\partial S^{2}}+0.03 S \frac{\partial C(\tau, S)}{\partial S}-0.03 C(\tau, S) \\
& 0 \leq S \leq 10,0 \leq \tau \leq 1 \\
& C(0, S)=\max (S(0)-E, 0), C(\tau, 0)=0, C(\tau, S) \approx S-E e^{-r \tau}
\end{aligned}
$$

Contoh di atas menghasilkan grafik perubahan nilai opsi (Black-Scholes) dari waktu ke waktu dalam bentuk dua dimensi (Gambar 2) maupun tiga dimensi (Gambar 3) seperti berikut.

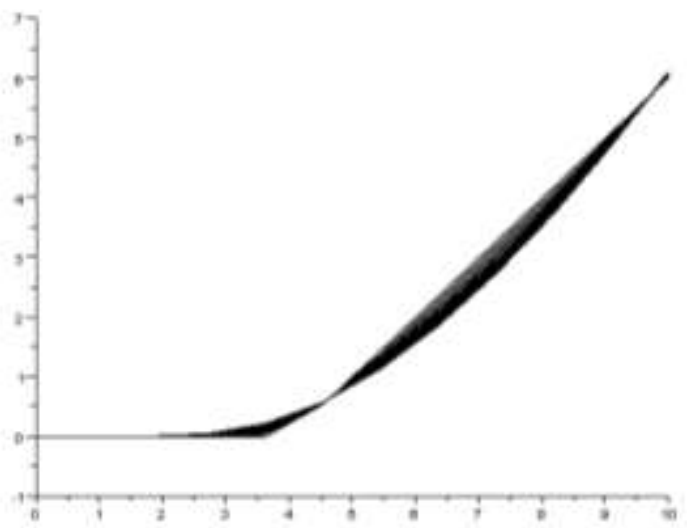

Gambar 2. Perubahan nilai opsi (Black-Scholes) dari waktu ke waktu dalam bentuk dua dimensi

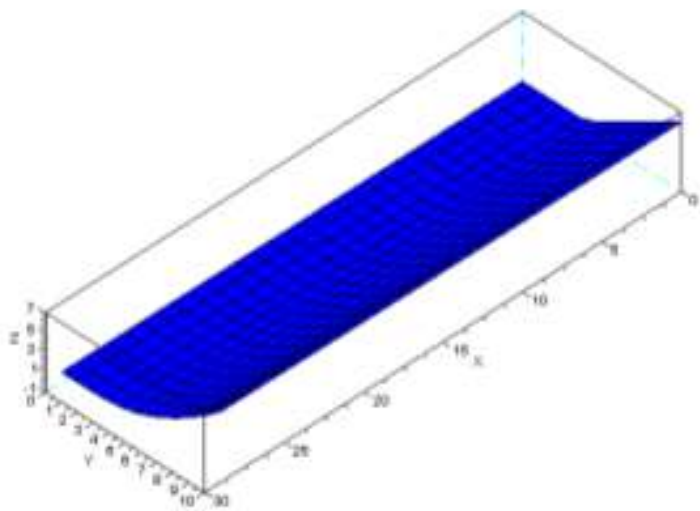

Gambar 3. Perubahan nilai opsi (Black-Scholes) dari waktu ke waktu dalam bentuk tiga dimensi

\section{KESIMPULAN}


Telah didemonstrasikan implementasi penyelesaian numerik persamaan differensial parsial evolusi dengan satu dimensi spasial dalam SCILAB dengan memanfaatkan rutin untuk menyelesaikan masalah syarat batas yang disediakannya.

Terbuka kesempatan pengembangan teknik metode garis lateral sebagai pustaka numerik di lingkungan SCILAB, menjadi pustaka yang setara dengan pdepe dengan mengikuti rancangan yang digariskan oleh Schryer [11]. Dengan kerangka yang diberikan Schryer tersebut, dimungkinkan memanfaatkan metode ini untuk menyelesaikan berbagai aplikasi.

\section{DAFTAR PUSTAKA}

[1] Ascher, U., J. Christiansen, and R.D. Russel. 1981. Collocation Software for Boundary Value ODEs, ACM Transactions on Mathematical Software, Vol.7, No.2.

[2] Ascher, U., R. M. Mattheij, and R.D Russel. 1988. Numerical Solution of Boundary Value Problem, New Jersey: Prentice-Hall.

[3] Campbell, S.L., J.P. Chancelier, and R.. Nikoukhah. 2005. Modeling and Simulation in Scilab/Scicos, Springer.

[4] Ekastrya, D., F. Ayatullah dan A.D. Garnadi. 2006. Menyelesaikan Persamaan Differensial Biasa - Syarat Batas dalam Scilab menggunakan bvode. JMA v7n1, 110.

[5] Garnadi, A.D. 2004. Masalah Syarat Batas Bebas Persamaan Diferensial Parsial Parabolik Satu Dimensi. JMA, v3n2, pp-pp.

[6] Madsen, N.K. and R.F. Sincovec. 1979. ALGORITHM 540: PDECOL, General Collocation Software for Partial Differential Equations, ACM Transactions on Mathematical Software, Vol. 5, No.3, 326-327.

[7] May, R.L. 1990. Numerical Solution of PDE's using The Methods of Lines, TR No. 2, Dept. Math., RMIT.

[8] Poulikakos, D. 1994. Conduction Heat Transfer, New Jersey: Prentice-Hall International.

[9] Schryer, N.L. 1990. Designing Software for One-Dimensional Partial Differential Equations, ACM Transactions on Mathematical Software. Vol. 16, No.1,72-85.

[10] Skeel, R.D. and M. Berzins. A Method for the Spatial Discretization of Parabolic Equations in One Space Variable, SIAM J. Sci.Stat.Comp., v11, 1-32.

[11] Jensen, B., Jørgensen, P.L. and Grosen, A., 2001. A finite difference approach to the valuation of path dependent life insurance liabilities. The Geneva Papers on Risk and Insurance Theory, 26(1), pp.57-84. 


\section{PENYELESAIAN MASALAH SYARAT BATAS PERSAMAAN DIFERENSIAL BIASA DALAM SCILAB}

Diuraikan penggunaan rutin bvode di lingkungan SCILAB untuk menyelesaikan masalah syarat batas sistem persamaan diferensial biasa. Tulisan ini bersifat pedagogis dengan tujuan dimana pengguna dapat mempergunakan solver bvode yang tersedia di lingkungan SCILAB untuk memecahkan masalah syarat batas secara numeric dari $\mathrm{MKO}$, setelah membaca uraian penggunaan rutin pemecahan masalah syarat batas. Penggunaan rutin digambarkan dengan tiga contoh masalah syarat batas.

Persamaan Diferensial Biasa (PDB) sering muncul sebagai model permasalahan dalam berbagai bidang ilmu pengetahuan. Pencarian solusi PDB diperlukan untuk memperoleh interpretasi dari model permasalahan semula. Solusi analitik dari suatu PDB tidak selalu mudah diperoleh, sehingga metode numerik diperlukan untuk mendapatkan solusi permasalahan.

Ada kalanya solusi yang sangat spesifik ingin didapatkan dari suatu sistem PDB dengan cara menentukan nilai-nilai awal pada lebih dari satu titik $x$. Permasalahan seperti ini dikenal dengan nama Masalah Syarat Batas (MSB), yang dapat dinyatakan oleh :

$$
\begin{aligned}
y^{n} & =f\left(x, y, y^{\prime}, y^{n}, \ldots, y^{n-1}\right) \\
y\left(a_{1}\right) & =b_{1} \\
y\left(a_{2}\right) & =b_{2}
\end{aligned}
$$

Dalam lingkungan Scilab, sebuah rutin untuk menyelesaikan MSB berdasarkan metode kolokasi disediakan, rutin ini bernama bvode. Metode kolokasi juga digunakan dalam lingkungan MATLAB untuk rutin bvp4c yang disediakannya.

Tulisan ini merupakan sebuah tutorial yang memberikan penuntun bagaimana memformulasikan masalah (menyusun perintah), untuk mendapatkan solusi numerik, dan menggambarkan solusi secara grafis dari MSB yang berasal 
dari Masalah Kontrol Optimum (MKO) dengan menggunakan rutin bvode. Tulisan ini juga merupakan studi pendahuluan numerik atas ketersediaan lingkungan pemecah masalah numerik (numerikal problem solving environment $\{\mathrm{PSE}\})$ yang bersifat open-source sebagai alternatif dari PSE komersial populer MATLAB yang menawarkan rutin bvp4c untuk memecahkan MSB.

Tujuan tulisan ini bersifat pedagogis yang menguraikan secara sederhana bagaimana MKO didapatkan solusinya dengan cara menyelesaikan secara numerik MSB sebuah PDB. Dengan demikian, seorang pemula dapat mempergunakan bvode untuk menyelesaikan MSB yang dihadapinya tanpa kesulitan.Selain itu, contoh yang diberikan muncul dari masalah perkuliahan yang biasanya ditemui di tahun ketiga atau keempat di perguruan tinggi.Selain itu, tulisan ini bertujuan untuk menyediakan dokumentasi tertulis berbahasa Indonesia. Tujuan lainnya ialah memberikan teladan penggunaan Open Source dilingkungan komputasi matematika di Indonesia, yang secara tidak langsung memberi dukungan pada proyek nasional IGOS (Indonesia Goes Open Source).

Tulisan ini disusun dengan urutan sebagai berikut.Pertama diuraikan formulasi masalah control optimum, yang dilanjutkan dengan deskripsi dari bvode. Kemudian diperlihatkan penggunaannya untuk sebuah contoh MKO sebagai masalah syarat batas yang diselesaikan menggunakan bvode. Untuk kepentingan pedagogis, diberikan dua contoh MSB yang diselesaikan menggunakan bvode dalam lingkungan Scilab. Kemudian diakhiri oleh kesimpulan serta berbagai kemungkinan pekerjaan lanjutan.

\section{DESKRIPSI bvode}

Rutin bvode yang tersedia dalam PSE Scilab, merupakan perangkat simulasi untuk menyelesaikan MSB. Rutin bvode pada dasarnya mempergunakan 
pustaka COLNEW yang merupakan perbaikan dari rutin program COLSYS ([1], [2]) yang berlandaskan metode kolokasi serta ditulis dalam bahasa permrograman FORTRAN. Tidak seperti solver PDB pada umumnya, bvode tidak mengharuskan pengguna mengubah persamaan diferensial orde tinggi menjadi sistem persamaan diferensial orde satu. Selain itu, bvode mampu menyelesaikan MSB di sejumlah titik (multipoint BVP).

Bentuk MSB yang diasumsikan oleh bvode ialah:

$$
\begin{gathered}
\frac{d^{m_{i}} y_{i}}{d x^{m_{i}}}=f_{i}\left(x, y(x), \frac{d y}{d x}, \ldots, \frac{d^{m_{i}-1} y_{i}}{d x^{m_{i}-1}}\right), \quad 1 \leq i \leq n_{c}, \\
g_{j}\left(\zeta_{j}, y\left(\zeta_{j}\right), \ldots, \frac{d^{m_{*}} y}{d x^{m_{*}}}\left(\zeta_{j}\right)\right)=0, \quad j=1, .
\end{gathered}
$$

Dengan merupakan posisi dimana syarat batas berlaju dan $a_{L} \leq \zeta_{j}$. Agar notasi tidak menyulitkan, tuliskan

$$
\begin{aligned}
& m_{*}=m_{1}+m_{2}+\cdots+m_{n_{e}} \\
& z(y)=\left[y, \frac{d y}{d x}, \ldots, \frac{d^{m_{*}} y}{d x^{m_{*}}}\right] .
\end{aligned}
$$

Dengan demikian, bentuk umum MSB yang diasumsikan oleh bvode ialah

$$
\begin{gathered}
\frac{d^{m_{i}} y_{i}}{d x^{m_{i}}}=f_{i}(x, z(y(x))), \quad 1 \leq i \leq n_{c}, \quad a_{L} \leq \zeta_{j} \leq a_{R}, \\
g_{j}\left(\zeta_{j} z\left(y\left(\zeta_{j}\right)\right)\right)=0, \quad j=1, .
\end{gathered}
$$

Rutin bvode memiliki kemampuan untuk menyelesaikan MSB yang linear maupun non-linear. Karena itu rutin ini mengharuskan pengguna menyusun sendiri matriks Jacobian dari PDB yang hendak diselesaikan, maka untuk beberapa masalah, tingkat kerumitan yang paling besar akan terasa pada penyusunan matriks Jacobian ini. 
Seperti halnya fungsi lain pada SCILAB, rutin bvode memiliki tata cara pemanggilan sebagai berikut ini

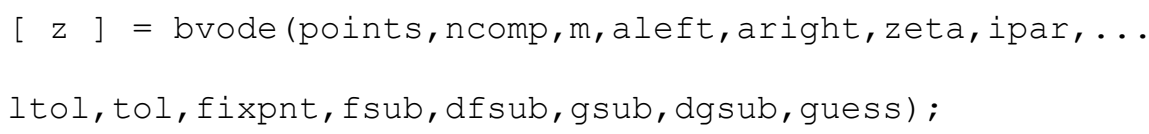

dengan z merupakan vektor baris yang berisi solusi numerik dari MSB yang ingin diselesaikan. Komponen z (i, : ) merepresentasikan turunan ke-(i-1) dari solusi pada selang domain. Sebagai contoh, $z(1,:)$ menyatakan $y, z(2,:)$ menyatakan $y^{\prime}$, dan seterusnya hingga $z\left(m^{*},:\right)$ menyatakan $y^{\left(m^{*}-1\right)}$.

Lima argumen terakhir yang diperlukan bvodeberbentuk fungsi yang harus didefinisikan sendiri oleh pengguna, sedangkan argumen lainnya merupakan informasi yang diperlukan bvode untuk dapat mencari solusi numerik berkaitan dengan MSB yang ingin diselesaikan.Berikut adalah penjelasan kegunaan masing-masing parameter yang digunakan oleh bvode.

z $\quad$ : Solusi dari PDB yang dievaluasi atas mesh yang diberikan oleh points.

Points : Array yang menyimpan titik di selang domain dimana MSB akan dicari solusinya.

Ncomp : Jumlah persamaan diferensial. Syaratnya haruslah ncomp $\leq 20$.

M : Vektor dengan panjang ncomp, yang isinya $m(j)$ berupa orde dari persamaan diferensial ke-j. Orde dari persamaan diferensial harus disyaratkanm $(j) \leq 4$.

Aleft : Ujung kiri dari selang domain dimana $y$ didefinisikan.

Aright : Ujung kanan dari selang domain dimana $y$ didefinisikan.

zeta : Isi zeta $(j)$ berisi titik syarat (batas) tambahan ke-j. Isi harus diurutkan sehingga zeta $(j) \leq$ zeta $(j+1)$. Semua titik syarat tambahan (batas) harus pada titik mesh di semua mesh yang digunakan. Khususnya, titik tersebut harus merupakan bagian dari mesh awal. Perhatikan pula uraian lebih rinci mengenai parameter ipar(11) dan fixpnt di bawah ini.

ipar : Array berentri bilangan bulat dengan ukuran sedikitnya 11. Daftar parameter dari ipar akan diuraikan kemudian. 


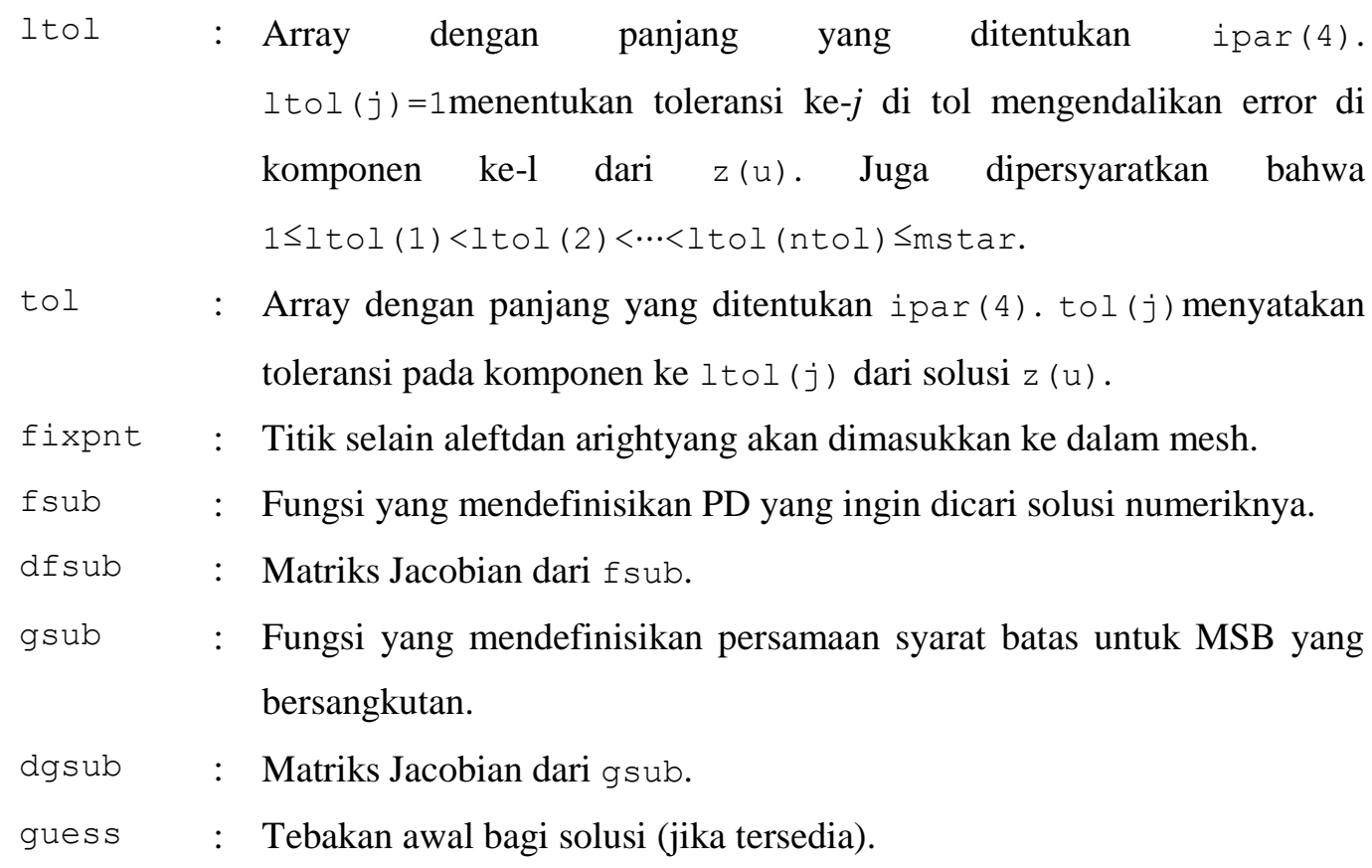
ltol $(j)=1$ menentukan toleransi ke- $j$ di tol mengendalikan error di komponen ke-1 dari $\mathrm{z}(\mathrm{u})$. Juga dipersyaratkan bahwa $1 \leq$ ltol $(1)<$ ltol $(2)<\cdots<$ ltol $($ ntol $) \leq$ mstar.

tol : Array dengan panjang yang ditentukan ipar $(4)$. tol $(j)$ menyatakan toleransi pada komponen ke ltol $(j)$ dari solusi z $(u)$.

fixpnt : Titik selain aleftdan arightyang akan dimasukkan ke dalam mesh.

fsub : Fungsi yang mendefinisikan PD yang ingin dicari solusi numeriknya.

dfsub : Matriks Jacobian dari fsub.

gsub : Fungsi yang mendefinisikan persamaan syarat batas untuk MSB yang bersangkutan.

dgsub : Matriks Jacobian dari gsub.

guess : Tebakan awal bagi solusi (jika tersedia).

Dari kelimabelas parameter di atas, argumen ipar adalah argumen yang paling panjang.Argumen ini memiliki 11 komponen yang secara keseluruhan memberi kesempatan pengguna untuk mengatur setting pada metode numerik yang digunakan bvode.Sebagian komponen dari parameter ipar berhubungan langsung dengan beberapa argumen bvode pada daftar parameter di atas. Sebagian besar dari komponen-komponen tersebut memiliki nilai default nol. Karena jumlah komponennya yang terbilang cukup banyak, ada baiknya jika dibuat variabel berdimensi $1 \times 11$ yang berisi nilai nol (default) sebelum mengisi komponen-komponen yang tidak bernilai default, yaitu

ipar $=\operatorname{zeros}(1,11) ;$.

Isikan masing-masing komponen parameter ipar berdasarkan keterangan yang didaftarkan di bawah ini:

ipar(1) : $=0$ jika MSB linear dan = 1 jika MSB non-linear.

ipar (2) : Banyaknya titik kolokasi per subinterval $(=k)$ dimana orde maksimum $\mathrm{PD} \leq k \leq 7$. Jika ipar (2)=0maka secara default $\mathrm{k}=\max (\max$ $m(i)+1,5-\max m(i))$. 
ipar(3) : Banyaknya subinterval pada mesh awal ( $=n)$.

Jika ipar $(3)=0$ maka secara default $n=5$.

ipar(4) : Banyaknya komponen solusi beserta turunannya yang diberi toleransi (=ntol), dengan aturan $0 \leq \mathrm{ntol} \leq \mathrm{m}^{*}$.

ipar(5) : Nilai yang menentukan banyaknya subinterval maksimum (nmax) pada selang domain. Pilihlah ipar(5) berdasarkan rumus berikut:

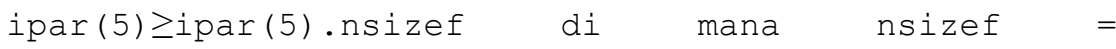
$4+3 m *+(5+k d) \cdot k d m+(2 m *-n r e c) \cdot 2 m *$ dengan nrec adalah banyaknya syarat batas pada ujung kanan selang domain ipar(5) diperuntukkan evaluasi pada titik-titik selang real.

ipar(6) : Nilai yang menentukan banyaknya subinterval maksimum nmax pada selang domain. Pilihlah ipar(6) berdasarkan rumus berikut:

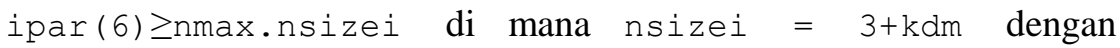
$\mathrm{kdm}=\mathrm{kd}+\mathrm{m}^{*} ; \quad \mathrm{kd}=\mathrm{k} \cdot \mathrm{ncomp} ;$ ipar (6) diperuntukkan evaluasi pada titik-titik integer.

ipar(7) : Kontrol output berikan nilai berikut: $=-1$ untuk printout diagnostik penuh $=0$ untuk printout sederhana. $=1$ tanpa printout.

ipar (8) : $\quad=0$ untuk mesh awal seragam.

ipar(9) : = 0 jika tidak tersedia tebakan awal bagi solusi. = 1 jika tebakan awal tersedia pada fungsiguess.

ipar(10) $=0$ jika masalah bersifat reguler. $=1$ jika iterasi nonlinear tidak bergantung pada kekonvergenan dari iterasi sebelumnya (hanya digunakan jika ipar $(1)=1$ ). = 2 jika proses ingin dihentikan setelah (a)terjadi dua kali nonkonvergen berturut-turut, atau (b)pendekatan galat didapatkan untuk pertama kalinya.

ipar(11) : Banyaknya titik selain ujung-ujung selang domain yang akan dimasukkan ke dalam mesh (dimensi dari argumen fixpnt). 


\section{CONTOH}

Untuk kepentingan pedagogis, dibahas tiga contoh bagaimana menyelesaikan MSB dengan mempergunakan bvode, dengan contoh terakhir yang berupa contoh MKO sebagai MSB. Selain itu, ditunjukkan pula bagaimana cara menggambar masing-masing komponen solusi numerik yang didapat dari bvode.

Contoh 1. Dalam contoh ini diberikan ilustrasi bagaimana mencari solusi numerik dari MSB yang melibatkan parameter yang tidak diketahui. Permasalahannya ialah menghitung nilai eigen dari persamaan Mathieu berikut ini,

$y^{\prime \prime}+(\lambda-2 q \cos (2 x)) y=0$

pada selang , dengan syarat batas $y^{\prime}\left(\mathrm{0}, \quad y^{\prime}(\pi \quad\right.$ untuk

Solusi dinormalisasi dengan cara menetapkan solusi memenuhi $y(0$. Permasalahan sesungguhnya ialah mencari nilai yang memenuhi syarat batas $y^{\prime}(\pi$. Nilai tebakan awal bagi menjadi keharusan dalam menyelesaikan masalah ini.MSB di atas diimplementasikan dalam SCILAB sebagai berikut ini.Persamaan diferensialnya didefinisikan dengan skrip berikut.

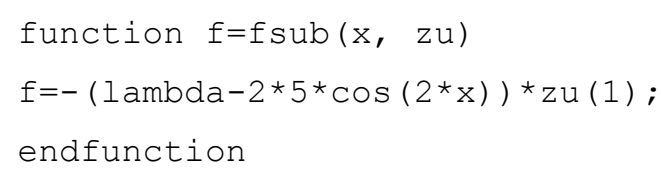

Untuk persamaan di atas, diperlukan matriks Jacobian yang ditulis dengan skrip seperti berikut ini.

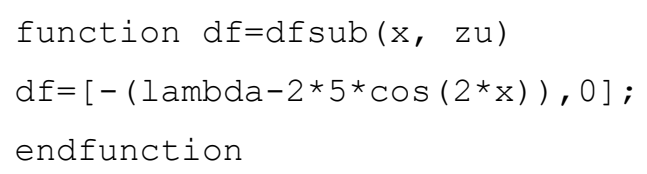

Sementara syarat batasnya diberikan oleh: 


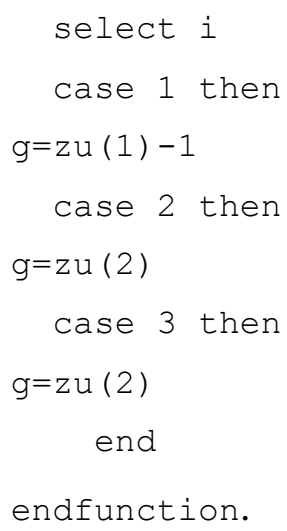

Untuk syarat batas tersebut di atas, diperlukan matriks Jacobian, yaitu

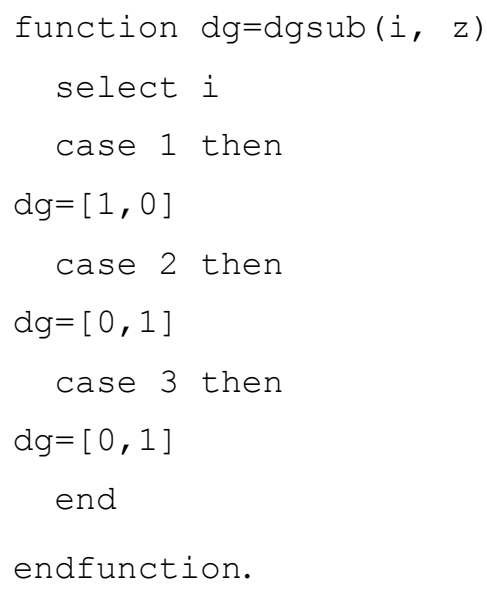

Berikut sejumlah parameter yang diperlukan, yaitu

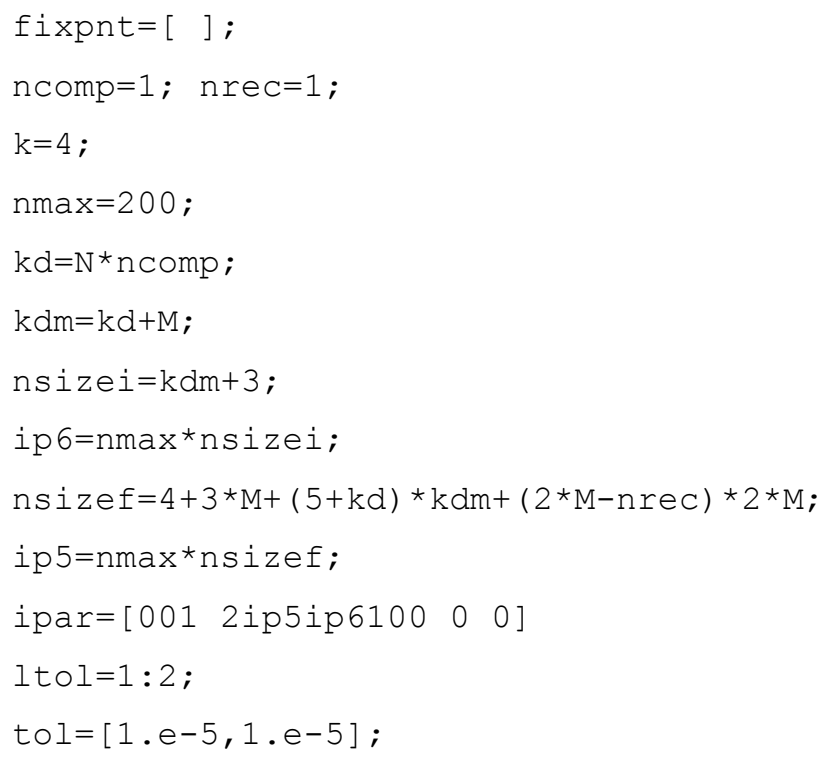


Karena tebakan awal bagi solusi y tidak tersedia maka fungsi guess didefinisikan seperti di bawah ini.

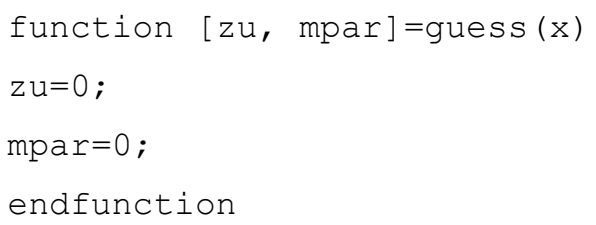

Jika tebakan awal bagi nilai eigen dipilih $=15$, maka untuk menyelesaikan MSB pada persamaan (7) sekaligus mendapatkan nilai pendekatan untuk dapat dilakukan dengan menambahkan loop seperti pada listing berikut,

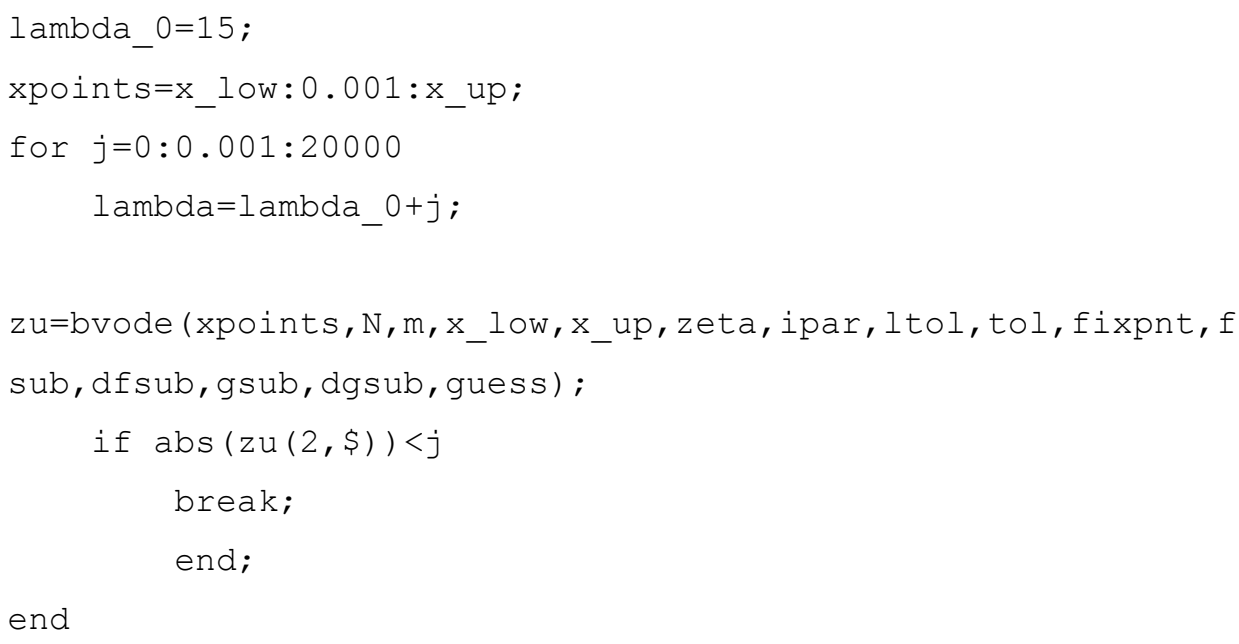

Untuk melihat gambar grafik solusi numerik untuk $y(x)$ yang dihasilkan bvode dan untuk mengetahui nilai yang didapat dari loop di atas, perintah berikut dengan cepat akan menampilkan keduanya:

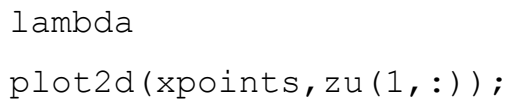

Dari hasil perhitungan yang dilakukan oleh bvode beserta loop di atas, didapat nilai pendekatan $=16.058$ dan gambar grafik solusi $y(x)$ seperti yang terlihat pada Gambar 1. Perhitungan di atas mempergunakan mesh dengan lebar kisi $\Delta x=0.001$ yang seragam untuk selang $[0, \pi]$. 


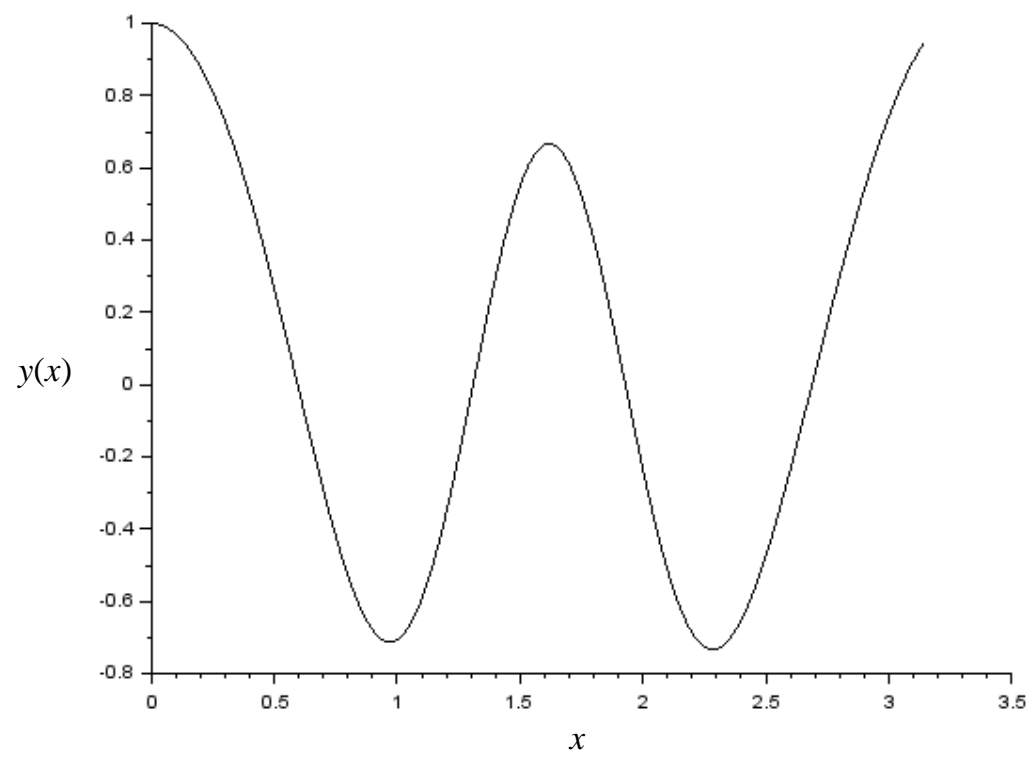

Gambar 1 Fungsi eigen dari persamaan Mathieu terkait dengan nilai eigen yang digunakan dalam artikel

Contoh 2. Pada contoh berikut diberikan sebuah MSB yang berasal dari formula kredibilitas yang memungkinkan aktuaris untuk menyeimbangkan dua hal, yaitu keakuratan dan kelinearan [9]. Berikut merupakan MSB untuk kasus di mana sebaran marginal ( ) dari besarnya klaim( ) ialah tak nol pada suatu interval terbatas , lihat Young [10].

$\frac{h}{f(x)}\left[f(x) d^{\prime \prime}(x)\right]^{\prime \prime}+d(x)=\mu(x)$,

dengan

$d^{\prime \prime}(a)=d^{\prime \prime}(b)=d^{\prime \prime \prime}(a)=d^{\prime \prime \prime}(b)=0$.

Pada contoh ini, misalkan $f(x)$ pada interval,$\quad h=0$, dan

$\mu(x)=\frac{2}{(x+2) \ln 1.5}-2+\frac{2}{(x+2)} \int_{1}^{0.5 x+1} \frac{3-2 \theta}{\ln 1.5-\ln \theta} d \theta$.

Misalkan pula

$v(x)=\int_{1}^{0.5 x+1} \frac{3-2 \theta}{\ln 1.5-\ln \theta} d \theta$,

sehingga 
$v^{\prime}(x)=\frac{1-x}{2[\ln 1.5-\ln (0.5 x+1)]}$.

Dengan demikian, persamaan (10) menjadi

$$
\begin{aligned}
0.0025 d^{m \prime}(x)+d(x) & =\frac{2}{(x+2) \ln 1.5}-2+\frac{2}{(x+2)} v(x) \\
d^{n n}(x) & =\frac{1}{0.0025}\left[\frac{2}{(x+2) \ln 1.5}-2+\frac{2}{(x+2)} v(x)-d(x)\right] .
\end{aligned}
$$

Jadi, MSB untuk kasus tersebut ialah

$$
\begin{aligned}
& v^{\prime}(x)=\frac{1-x}{2[\ln 1.5-\ln (0.5 x+1)]^{\prime}} \\
& d^{n v}(x)=\frac{1}{0.0025}\left[\frac{2}{(x+2) \ln 1.5}-2+\frac{2}{(x+2)} v(x)-d(x)\right]
\end{aligned}
$$

dengan

$v(0)=d^{\prime \prime}(0)=d^{n}(1)=d^{n \prime}(0)=d^{n \prime}(1)=0$.

MSB di atas diimplementasikan dalam SCILAB sebagai berikut.Persamaan diferensialnya didefinisikan dengan skrip berikut.

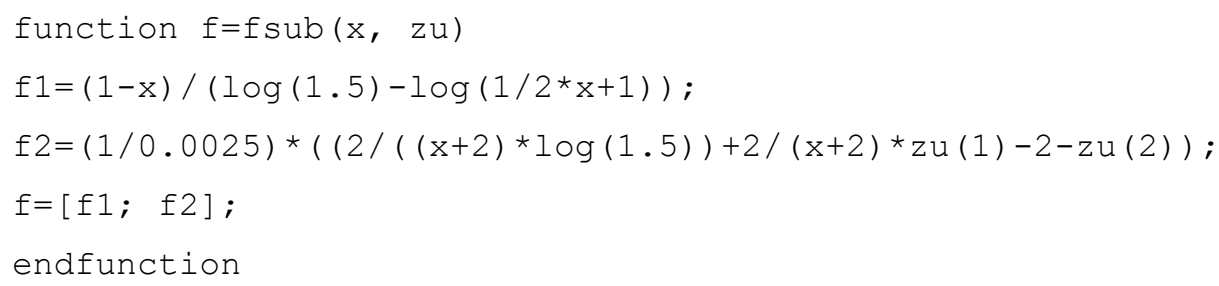

Untuk persamaan di atas, diperlukan matriks Jacobian yang ditulis dengan skrip seperti berikut ini.

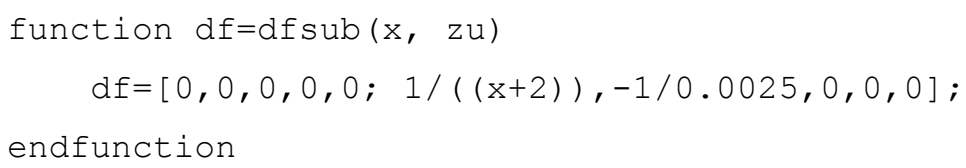

Sementara syarat batasnya diberikan oleh:

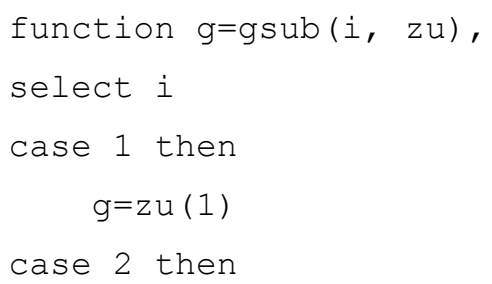




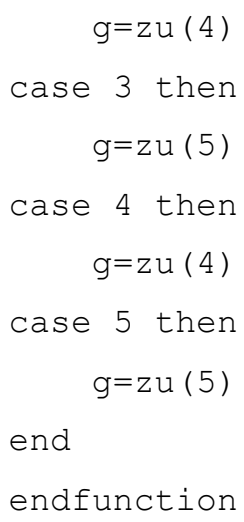

Untuk syarat batas tersebut, diperlukan matriks Jacobian, yaitu

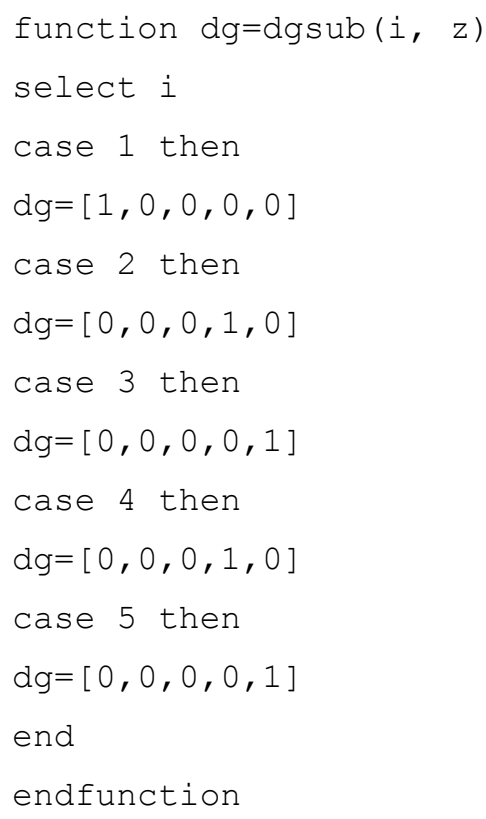

MSB di atas, diselesaikan di atas selang [0,1] dengan lebar kisi $\Delta t=0.01$ yang seragam, berikut sejumlah parameter yang diperlukan, yaitu

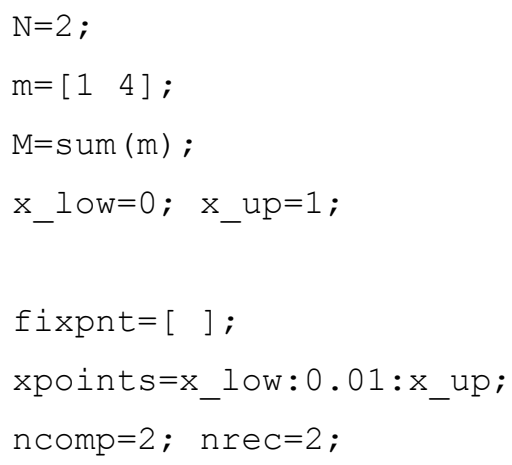




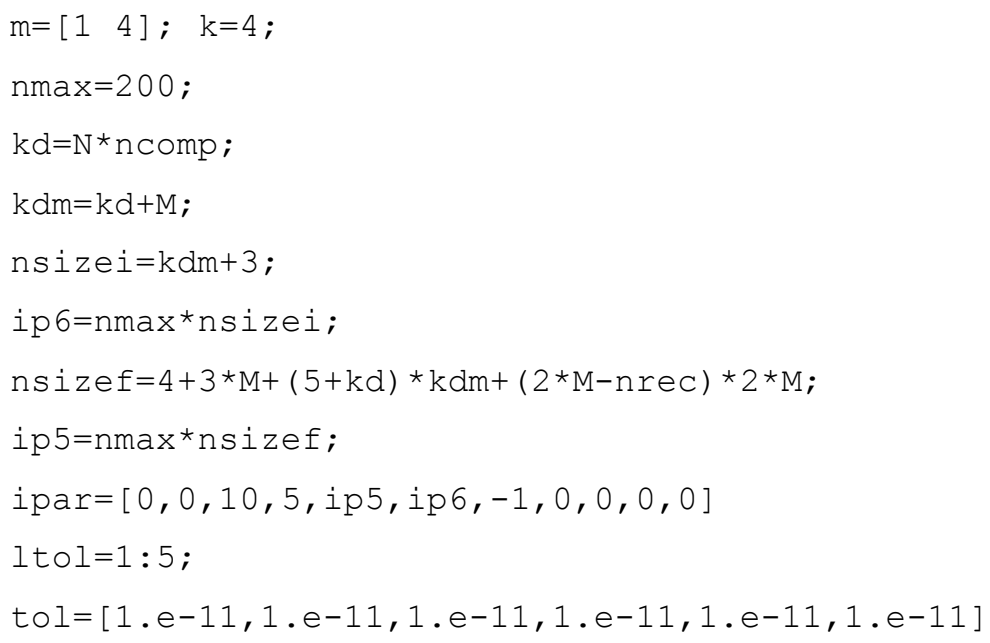

dan kita berikan fungsi tebakan awal, yaitu

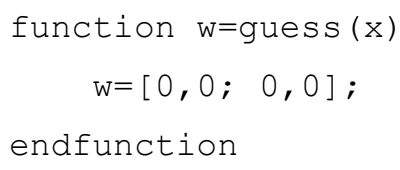

Kemudian untuk memperoleh solusi numerik MSB, diberikan dalam skrip SCILAB berikut zu=bvode (xpoints, N, m, x_low, x_up, zeta, ipar,ltol,tol,fixpnt, fs ub, dfsub, gsub, dgsub, guess )

Solusi numerik yang diperoleh, ditampilkan oleh Scilab dengan memberikan skrip berikut ini plot (xpoints, zu (1, :)) .

Tampilan grafisnya diperlihatkan pada Gambar 2. 


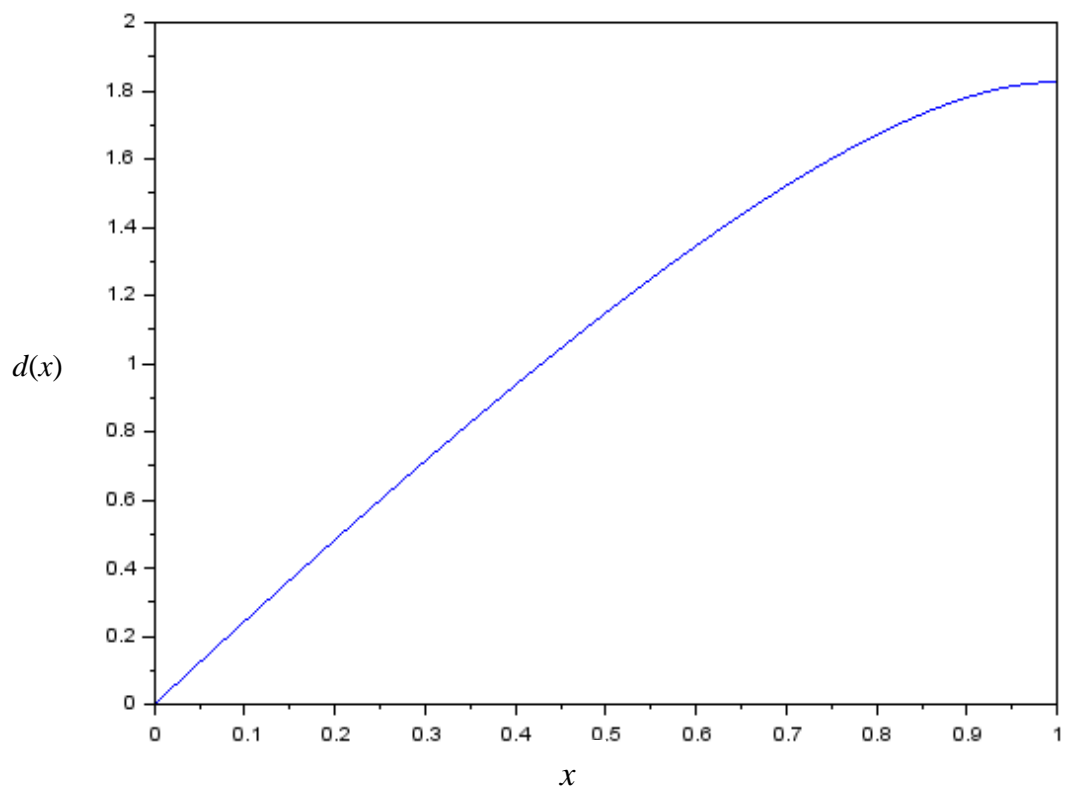

Gambar 2. Solusi optimum $(d)$ dengan $h=0.0025$.

Contoh 3. Pada contoh berikut diberikan sebuah MSB yang berasal dari Kontrol Optimum. Biasanya, syarat cukup untuk kontrol optimum berupa MSB, yang biasanya lebih mudah menyelesaikannya untuk banyak masalah sederhana.

Perhatikan masalah sistem terkontrol

$y^{\prime}=y^{2}+v$

dan kita inginkan kontrol $v$ mengendalikan lintasan dari 2 pada saat $t=0$ ke -1 pada saat $t=10$. Dengan demikian, kita inginkan $v$ meminimumkan ongkos kuadratik berikut

$$
I(y, v)=\int_{0}^{10}\left(y^{2}+10 v^{2}\right) d t .
$$

Fungsi ongkos ini menyebabkan variabel keadaan $y$ dan variabel kontrol $v$ terpenalisasi, sehingga menyebabkan variabel keadaan dan kontrol menjadi kecil.

Syarat cukup dapat diperoleh dengan mendefinisikan fungsi Hamiltonian

$$
H=\left(y^{2}+10 v^{2}\right)+\lambda\left(y^{2}+v\right)
$$

dan kita tuliskan masalah syarat batas persamaan diferensial aljabar 


$$
\begin{aligned}
& y^{\prime}=\frac{\partial H}{\partial \lambda^{x}} \\
& \lambda^{\prime}=\frac{\partial H}{\partial y^{y}}
\end{aligned}
$$

$$
0=\frac{\partial H}{\partial v^{y}}
$$

$$
y(0)=2, y(10)=1,
$$

Bila $v$ dieliminasi, akan diperoleh MSB

$y^{\prime}=y^{2}+v_{x}$

$\lambda^{\prime}=-2 y-2 \lambda y$,

$0=20 v+\lambda$

$$
y(0)=2, y(10)=1 \text {, }
$$

MSB di atas diimplementasikan dalam SCILAB sebagai berikut ini.Persamaan diferensialnya didefinisikan dengan skrip berikut.

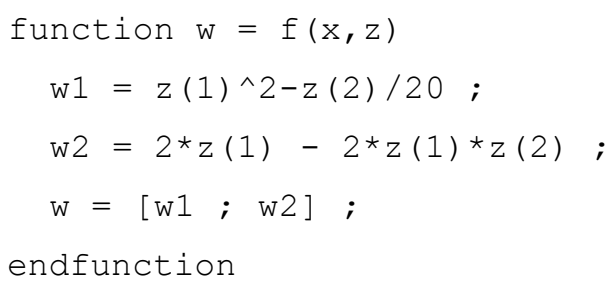

Untuk persamaan di atas, diperlukan matriks Jacobian yang ditulis dengan skrip seperti berikut ini.

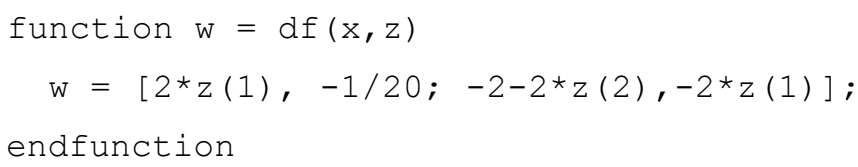

Sementara syarat batasnya diberikan oleh:

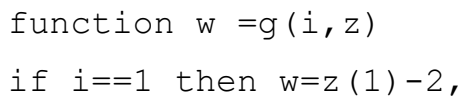


else $\mathrm{w}=\mathrm{z}(1)+1$;

end

endfunction.

Untuk syarat batas tersebut di atas, diperlukan matriks Jacobian, yaitu

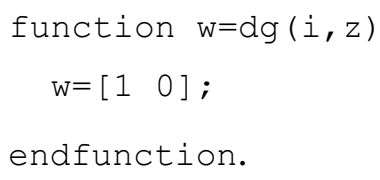

MSB di atas, diselesaikan di atas selang $[0,10]$ dengan lebar kisi $\Delta t=0.1$ yang seragam, berikut sejumlah parameter yang diperlukan, yaitu

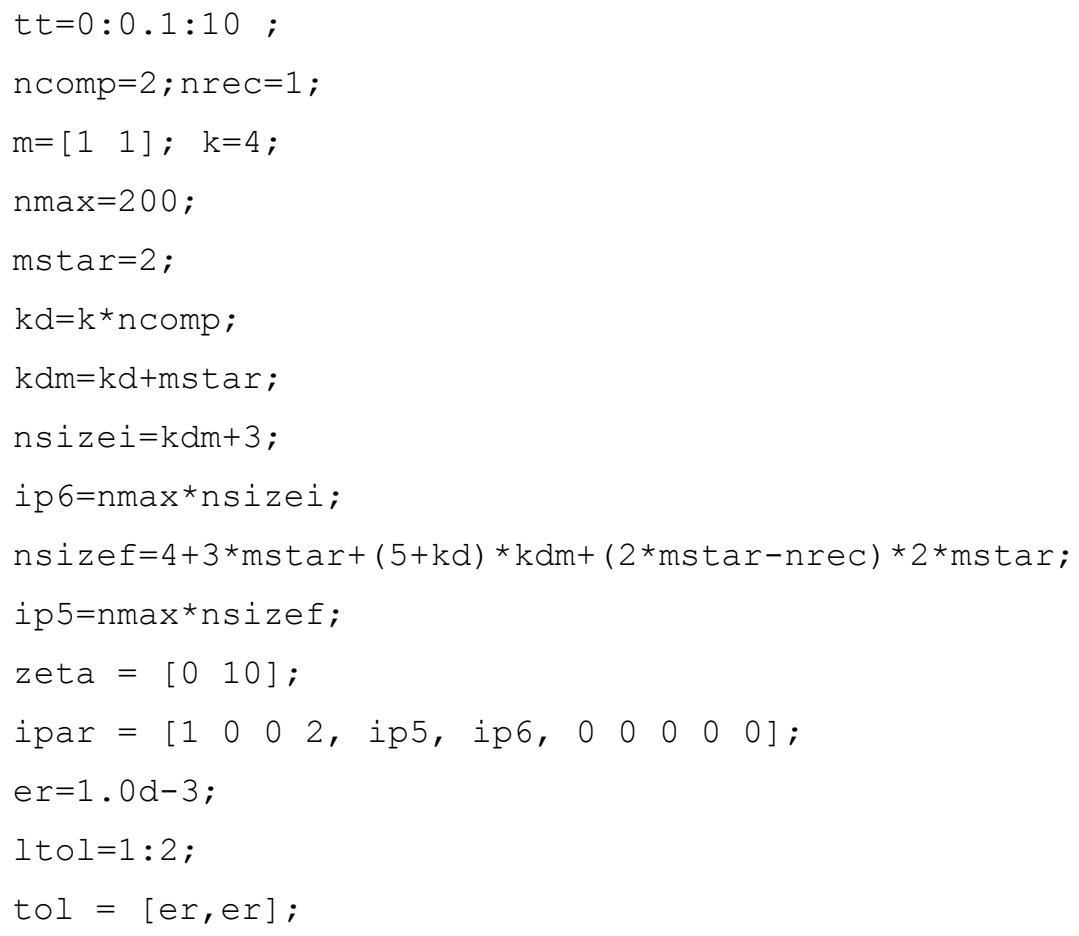

dan kita berikan fungsi tebakan awal, yaitu

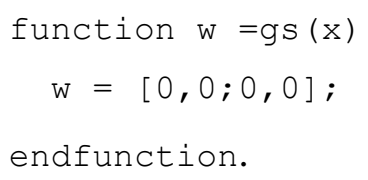

Kemudian untuk memperoleh solusi numerik MSB, diberikan dalam skrip SCILAB berikut 


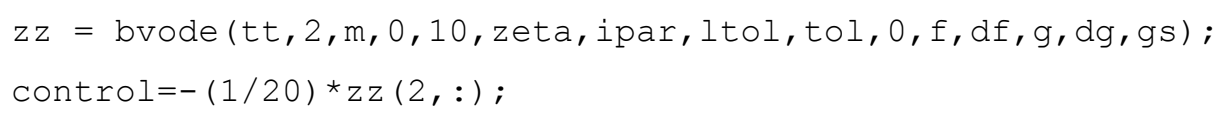

Solusi numerik yang diperoleh, ditampilkan oleh Scilab dengan memberikan skrip berikut ini

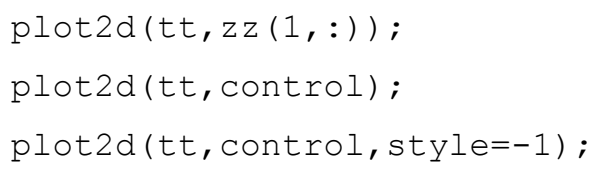

yang tampilan grafisnya diperlihatkan pada Gambar 3.

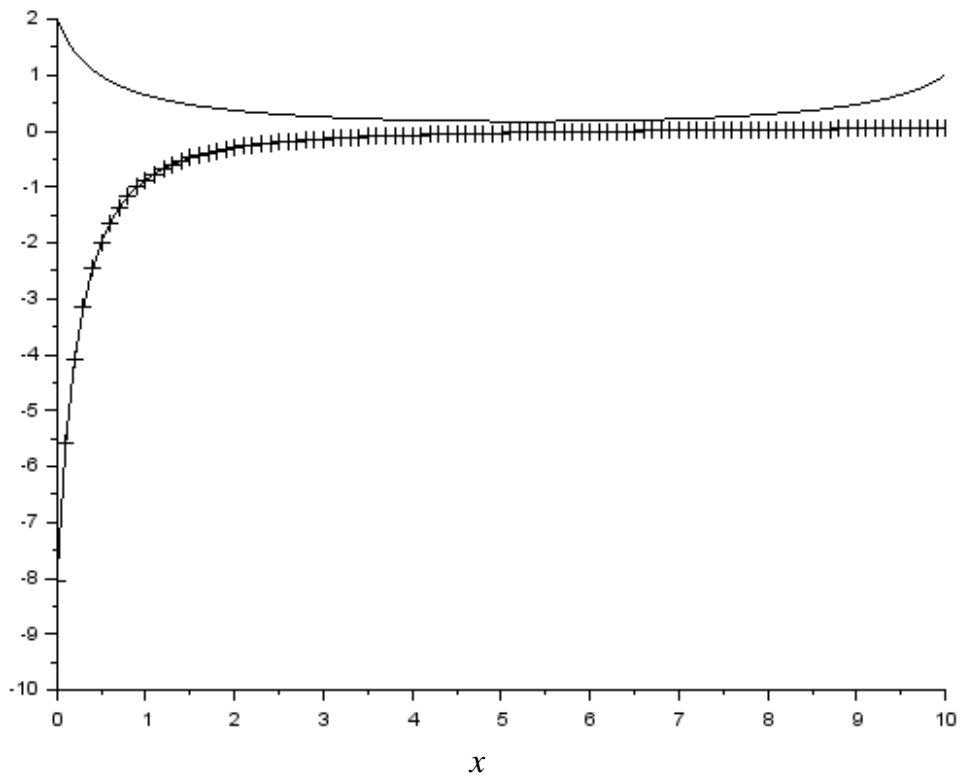

Gambar 3 Optimum $y$ (garis) dan kontrol $v$ (garis- $x$ ) untuk contoh 3.

\section{SIMPULAN}

Telah disampaikan bagaimana Masalah KO dapat diselesaikan sebagai masalah syarat batas, penggunaan MKO sering muncul sebagai model dari berbagai bidang ilmu. Karena untuk mendapatkan solusi analitik tidak selalu tersedia, metode numerik menjadi salah satu cara untuk memperoleh solusinya. Selain itu, dengan tersedianya rutin yang memudahkan pengguna untuk menyelesaikan MSB secara numerik, dimungkinkan melakukan simulasi secara 
berulang untuk menguji berbagai skenario pemodelan yang menggunakan MKO. Tulisan ini merupakan tutorial bagaiman menggunakan simulasi MSB dalam lingkungan problem solving environment SCILAB yang bersifat open source untuk menyelesaikan MKO. Perlu kiranya pengujian lebih lanjut atas rutin ini, antara lain menguji berbagai kasus di [7], yang memberikan serangkaian contoh MKO sebagai MSB, selain itu sebagaimana ditunjukkan di [11], bahwa syarat perlu dari MKO merupakan MSB dengan titik batas majemuk (multipoint BVP) memungkinkan bvode di SCILAB untuk digunakan. Ragam permasalahan MKO disampaikan di buku [12], yang membuka wawasan pentingnya MKO di dalam teknologi maupun ekonomi.

\section{DAFTAR PUSTAKA}

[1] Ascher U, Christiansen J, Russel RD. 1981. Collocation Software for Boundary-Value ODEs.ACM Transactions on Mathematical Software. 7(2).

[2] Ascher U, Mattheij RM, Russel RD, Numerikal Solution of Boundary Value Problem.New Jersey: Prentice-Hall, Englewood Cliffs.

[3] Campbell SL. Chancelier JP, Nikoukhah R. 2005.Modeling and Simulation in Scilab/Scicos. Springer.

[4] Higham DJ, Higham NJ. 2000.MATLABGuide. SIAM.

[5] Kierzenka J, Shampine L. 2001. A BVP solver on residual control and the Matlab PSE.ACM Transactions on Mathematical Software.27(3): 299-316.

[6] Moler CB. 2004.Numerikal Computing with MATLAB. SIAM.

[7] S. N. Avvakumov and Yu.N. Kiselev, 2000, Boundary value problem for ordinary differential equations with applications to optimal control, Spectral and evolution problems, V10, pp 147--155

[8] Layar bantuan SCILAB untuk rutin bvode.

[9] Kaas R,Goovaerts M, Dhaene J, Denuit M. 2009.Credibility theory. Modern Actuarial Risk Theory: Using R.203-229.

[10] Young VR. 1997. Credibility using a loss function from spline theory. Scandinavian Actuarial Journal. 1997(2): 160-185.

[11] Pesch, H.J., 1994. A practical guide to the solution of real-life optimal control problems. Control and cybernetics, 23(1), p.2.

[12] Pesch, H.J., 2002. Schlüsseltechnologie Mathematik: Einblicke in aktuelle Anwendungen der Mathematik. Springer-Verlag. 
FORMULASI MASALAH KONTROL OPTIMUM SEBAGAI MASALAH SYARAT BATAS

Disini kita inginkan untuk menentukan input $\mathbf{u}(t)$ yang meminimumkan fungsional scalar berbentuk:

$$
\mathcal{J}=\phi\left(\mathbf{x}\left(t_{f}\right)\right)+\int_{0}^{t_{f}} L(\mathbf{x}, \mathbf{u}, t) d t
$$

Jika diberikan kendala dinamika tak-linear berbentuk:

$$
\dot{\mathrm{x}}=\mathbf{f}(\mathbf{x}, \mathbf{u}, t), \quad \mathbf{x}(t=0)=\mathrm{x}_{0}
$$

Melalui kalkulus variasi, solutsi persamaan (1) dapat diperoleh melalui berupa MSB berikut

$$
\begin{aligned}
& \dot{\mathrm{x}}=\mathbf{f}(\mathrm{x}, \mathbf{u}, t), \quad \mathrm{x}\left(t_{0}\right)=\mathrm{x}_{0} \\
& \dot{\lambda}=-\frac{\partial H}{\partial \mathrm{x}}, \quad \boldsymbol{\lambda}\left(t_{f}\right)=\left.\frac{\partial \phi}{\partial \mathrm{x}}\right|_{t_{f}}
\end{aligned}
$$

Dengan $\lambda$ merupakan varibel co-state, dengan Hamiltonian $H \stackrel{\text { def }}{=} L+\lambda^{T} \mathbf{f}$

Serta input kontrol yang merupakan solusi dari:

$$
\frac{\partial L}{\partial \mathbf{u}}+\lambda^{T} \frac{\partial \mathbf{f}}{\partial \mathbf{u}}=0
$$


Persamaan (5) tidak trivial untuk menyelesaikannya, karena harus menyelesaikan MSB (3) dan (4) dengan kendala yang bersifat aljabar. 
- Persamaan Poisson dalam Semikonduktor

- Sel Surya Perovskite

- Dam problem

- Stefan Problem (Freeze Drying)

- American Option

- Biosensor

- Persamaan gelombang air cetek 